Archive for

Organic Chemistry

Arkivoc 2017, part iv, 222-235

\title{
Reaction of trifluoromethyl 1,3-dicarbonyl compounds with formaldehyde and esters of natural $\alpha$-aminoacids
}

\author{
Natalya N. Gibadullina, ${ }^{a}$ Dilara R. Latypova, ${ }^{a, b}$ Roman A. Novikov, ${ }^{* b, c}$ Yury V. Tomilov, ${ }^{b, c}$ \\ and Vladimir A. Dokicheva,b \\ a Ufa Institute of Chemistry of the Russian Academy of Sciences, 71 prospect Oktyabrya, \\ Ufa, 450 054, Russian Federation \\ ${ }^{b}$ Ufa State Aviation Technical University, 12 K. Marx Street, Ufa, 450 008, Russian Federation \\ c N. D. Zelinsky Institute of Organic Chemistry, Russian Academy of Sciences, 47 Leninsky prosp., \\ 119991 Moscow, Russian Federation \\ E-mail: novikovfff@bk.ru
}

Received 12-27-2016

Accepted 04-28-2017

Published on line $05-26-2017$

\section{Abstract}

Condensation of fluorinated 1,3-dicarbonyl compounds with formaldehyde and l-amino acid ester hydrochlorides in acetate buffer, $\mathrm{AcONa}-\mathrm{AcOH}(\mathrm{pH}$ 5.9), at room temperature gave chiral hexahydropyrimidines, both containing and lacking a trifluoroacetyl group at position 5 of the heterocycle. In contrast, the reaction of ethyl 3-oxo-4,4,4-trifluorobutanoate with formaldehyde and ethyl (S)-tyrosinate hydrochloride under the same conditions gave a new chiral tetrahydropyrimidinium salt containing the trifluoroacetate anion in good yield. It is interesting that one of the formaldehyde molecules acts as an oxidant in this process.

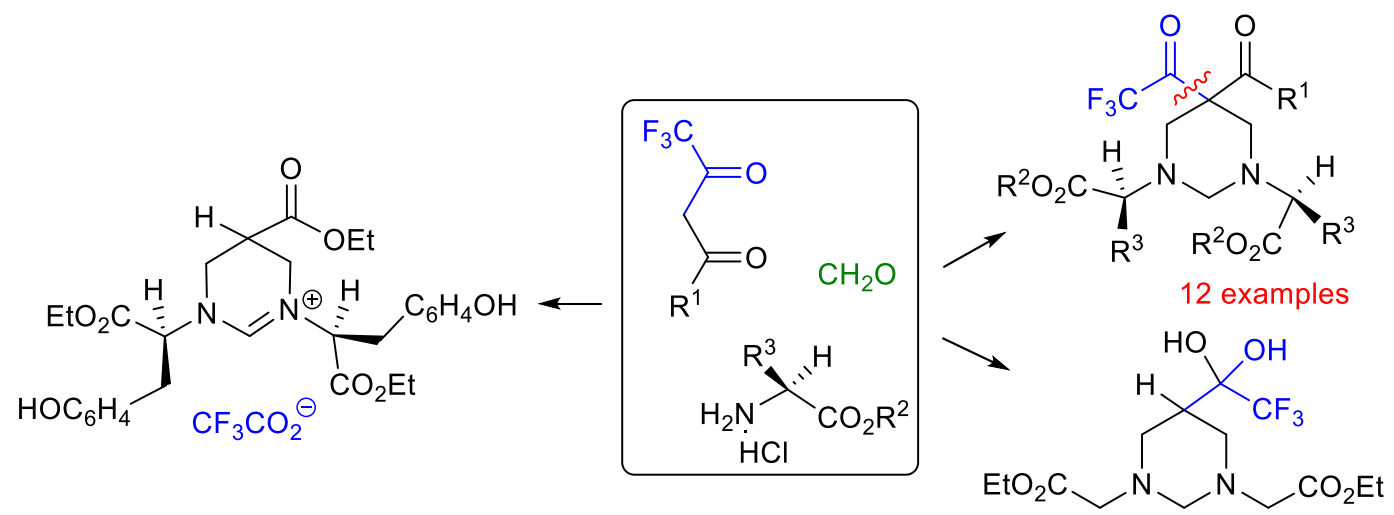

Keywords: Trifluoromethyl 1,3-dicarbonyl compounds, (S)-aminoesters, hexahydropyrimidines, chirality 


\section{Introduction}

The unique properties of the trifluoromethyl group, such as strong electron-withdrawing character, lipophilicity and metabolic stability, are widely used in the synthesis of new compounds for pharmaceutical and agrochemical industries as well as in materials technology. ${ }^{1}$ Replacement of a hydrogen atom for a fluorine has little effect on the molecule's geometry due to the similarity of their atomic radii, but the high electronegativity of fluorine strongly affects the overall electron-donating properties of a molecule. ${ }^{2}$ On a molecular level, this results in inhibition of certain metabolic pathways, including a change in membrane permeability and electrostatic interaction with the target. In terms of physiology, an increase in bioavailability and selectivity with respect to the pharmacological target are achieved. ${ }^{3}$

Hexahydropyrimidines belong to an important class of biologically active heterocycles with a broad range of physiological activity: antitumoral, ${ }^{4,5}$ cytotoxic, $^{3,6}$ antibacterial, ${ }^{7}$ antimicrobial, ${ }^{8}$ antiarrhythmic ${ }^{9}$ and antiviral (against hepatitis C). ${ }^{10}$ 5,5-Disubstituted hexahydropyrimidines are efficient against Ehrlich carcinoma and Staphylococcus aureus. ${ }^{11}$ Some hexahydropyrimidines containing a trifluoromethyl group are usually obtained by the Biginelli reaction from ethyl 4,4,4-trifluoroacetoacetate, an aldehyde, and urea or thiourea.,12,13 Several fluorine-containing 2-thia- or 2-oxahexahydropyrimidines manifest cytotoxic ${ }^{3}$ and antibacterial activity ${ }^{12}$ and are promising as selective antitumoral medicines. ${ }^{14}$

In this study we suggest a one-pot synthesis of optically active hexahydropyrimidine derivatives by reaction of trifluoromethyl 1,3-dicarbonyl compounds with formaldehyde and natural amino acid ester hydrochlorides under Mannich reaction conditions. Also, a one-pot method for the synthesis of a new chiral tetrahydropyrimidinium salt is presented.

The reactions of $\mathrm{CH}$-acids with aldehydes and primary amines under Mannich reaction conditions are among the convenient methods for synthesizing hexahydropyrimidine derivatives. These reactions are generally carried out in methanol or in water-methanol solutions at $65^{\circ} \mathrm{C}$ and $\mathrm{pH} 7.5-8.0^{15,16}$ (Scheme 1 ).

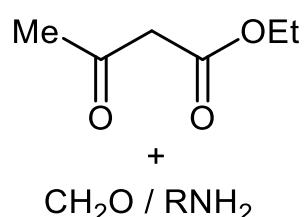

$\mathrm{R}=\mathrm{Me}, \mathrm{Pr}, \mathrm{i}-\mathrm{Pr}, \mathrm{Bu}, \mathrm{Bn},\left(\mathrm{CH}_{2}\right)_{2} \mathrm{OH}$

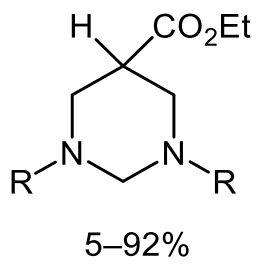

and

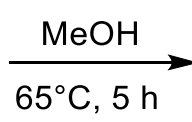

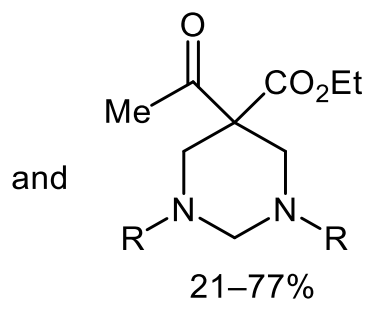

Scheme 1. Synthesis of hexahydropyrimidines under Mannich reaction conditions.

\section{Results and Discussion}

In continuation of studies ${ }^{15}$ on the synthesis of hexahydropyrimidines, we studied the reaction of fluorinecontaining 1,3-dicarbonyl compounds, namely ethyl 3-oxo-4,4,4-trifluorobutanoate (1a), 1,1,1-trifluoropentane-2,4-dione (1) and 1,1,1,5,5,5-hexafluoropentane-2,4-dione (1c), with formaldehyde and esters of natural amino acids under Mannich reaction conditions. Methyl ester hydrochlorides of $(S)$-alanine (2b), (S)valine (2c), (S)-leucine (2d) and ethyl ester hydrochlorides of glycine (2a), (S)-phenylalanine (2e), and (S)tyrosine (2f) were used as the amino esters. It was found that in all cases the reaction conditions used 
previously for non-fluorinated 1,3-dicarbonyl compounds did not provide tetrasubstituted hexahydropyrimidines due to easy elimination of the $\mathrm{CF}_{3} \mathrm{CO}$ group. Still, we succeeded in finding conditions where the trifluoroacetyl group was preserved for certain amino esters. The formation of the 1,3,5,5-tetrasubstituted hexahydropyrimidine moiety occurs most successfully at room temperature under conditions of sequential condensation of trifluoromethyl 1,3-dicarbonyl compounds with formaldehyde and amino ester hydrochlorides with a molar reagent ratio of $1: 15: 2$ or $1: 4: 2$ (depending on the $\mathrm{CH}$-acid used) in acetate buffer, AcONa-AcOH (pH 5.9). The use of $1.0 \mathrm{ml}$ acetate buffer for each one-mmol of a $\mathrm{CH}$-acid proved to be the optimum amount for this reaction.

A study of the effect of the nature of the starting reagents on the reaction pathway showed that the amine component considerably affected the likelihood that the trifluoroacetyl group at position 5 of the heterocycle would be preserved. In fact, the reaction of ethyl 3-oxo-4,4,4-trifluorobutanoate (1a) with an aqueous solution of formaldehyde and ethyl glycinate hydrochloride (2a) or methyl (S)-alaninate hydrochloride $\mathbf{2} \mathbf{2} \mathbf{b})$ results in hexahydropyrimidines $\mathbf{3 a}$ or $\mathbf{3 b}$ containing no trifluoroacetyl group (Table $\mathbf{1}$, entries 1 and 2). In general, this behavior of trifluoroacetyl derivatives is not surprising. For example, it is known ${ }^{16}$ that the reaction of ethyl 3-oxo-4,4,4-trifluorobutanoate (1a) with benzaldehyde in the presence of pyridine is accompanied by elimination of pyridinium trifluoroacetate.

Table 1. Synthesis of hexahydropyrimidines $\mathbf{3}$ and $\mathbf{4}$ from $\mathbf{1 a}, \mathbf{b}, \mathrm{CH}_{2} \mathrm{O}$ and various $\alpha$-amino esters

\begin{tabular}{|c|c|c|c|c|c|c|c|}
\hline$\sum_{\mathrm{F}_{3} \mathrm{C}}^{\mathrm{R}^{1}}=0$ & $+\mathrm{CH}_{2} \mathrm{O}+$ & 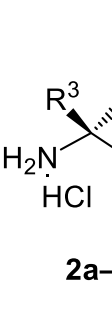 & $\mathrm{R}^{2} \frac{\mathrm{AcO}}{\mathrm{pH} 5}$ & $\frac{\mathrm{AcOH}}{\mathrm{t}, 24 \mathrm{~h}}$ & $\begin{array}{r}\mathrm{R}^{3} \quad \mathrm{R}^{2} \mathrm{O}_{2} \mathrm{C} \\
\text { 3a-d,f, } \mathbf{g}\end{array}$ & & $\begin{array}{l}\mathrm{R}^{2} \mathrm{O}_{2} \mathrm{C} \\
4 \mathrm{c}-\mathrm{f}\end{array}$ \\
\hline Entry & $\mathrm{CH}$-acid & $\mathrm{R}^{1}$ & $\begin{array}{c}\text { Amino } \\
\text { ester }\end{array}$ & $\mathrm{R}^{2}$ & $\mathrm{R}^{3}$ & \multicolumn{2}{|c|}{ Isolated yields (\%) } \\
\hline 1 & 1a & OEt & $2 a$ & Et & $\mathrm{H}$ & $3 a(62)$ & - \\
\hline 2 & 1a & OEt & $2 b$ & Me & Me & $3 b(56)$ & - \\
\hline 3 & 1a & OEt & 2c & Me & $\mathrm{CHMe}_{2}$ & $3 c(10)$ & $4 c(48)$ \\
\hline 4 & 1a & OEt & $2 d$ & $\mathrm{Me}$ & $\mathrm{CH}_{2} \mathrm{CHMe}_{2}$ & $\mathbf{3 d}(26)^{b}$ & $4 d(40)^{b}$ \\
\hline 5 & 1a & OEt & $2 e$ & Et & $\mathrm{CH}_{2} \mathrm{Ph}$ & - & $4 e(46)$ \\
\hline 6 & $1 b$ & Me & $2 a$ & Et & $\mathrm{H}$ & $3 f(42)^{c}$ & - \\
\hline $7^{d}$ & $1 b$ & Me & $2 a$ & Et & $\mathrm{H}$ & - & $4 f(70)$ \\
\hline $8^{d}$ & $1 b$ & $\mathrm{Me}$ & $2 f$ & Et & $\mathrm{CH}_{2} \mathrm{C}_{6} \mathrm{H}_{4} \mathrm{OH}-4$ & $3 g(46)^{c}$ & - \\
\hline
\end{tabular}

a Reaction conditions: molar ratio $1: \mathrm{CH}_{2} \mathrm{O}$ (33\% aqueous solution) : $\mathbf{2}=1: 15: 2, \mathrm{rt}, 24 \mathrm{~h}$.

${ }^{\mathrm{b}}$ Results after column chromatography.

' Yields were determined by NMR spectroscopy (benzene as internal standard).

d Molar ratio $\mathbf{1 b}: \mathrm{CH}_{2} \mathrm{O}: \mathbf{2}=1: 4: 2$. 
Unlike glycine and alanine esters, the reactions of 1a with formaldehyde and $(S)$-valine (2c) and especially (S)-leucine (2d) and (S)-phenylalanine (2e) ester hydrochlorides under the same conditions occurs with preservation of the $\mathrm{CF}_{3} \mathrm{CO}$ group. ${ }^{17}$ While in the case of $(S)$-valine the reaction mixture contains not only $\mathbf{4 c}$ but also $\sim 10 \%$ of defluorinated product $\mathbf{3 c}$ (entry 3), amino esters $\mathbf{2 d}$ and $\mathbf{2 e}$ selectively give fluorinated hexahydropyrimidines $4 \mathrm{~d}$ and $4 \mathrm{e}$ in 68 and $46 \%$ yields, respectively (entries 4, 5). However, certain precautions are also needed in this case in order to preserve the trifluoroacetyl group in the hexahydropyrimidine ring. For example, isolation of compound $\mathbf{4 d}$ by column chromatography on $\mathrm{SiO}_{2}$ resulted in deacylation of a proportion of the product to give compounds $\mathbf{3 d}$ and $\mathbf{4 d}$ in 26 and $40 \%$ yields, respectively. However, this phenomenon was not observed in the case of chromatography of hexahydropyrimidines $4 \mathrm{c}$ and $4 \mathrm{e}$ on $\mathrm{SiO}_{2}$.

In order to establish the absence of epimerization and to prove the formation of a single enantiomer we carried out the reaction of $\mathbf{1 a}$ with racemic leucine methyl ester $(\mathbf{2} \mathbf{d})$. In this case, according to the data of NMR spectra and chiral HPLC analysis, the target compound $\mathbf{4 d}$ is formed as four stereoisomers. Three of them are diastereomers, of which two represent meso-forms (Figure 1). At the same time, the corresponding compound obtained from (S)-leucine $\mathbf{2} \mathbf{d}$ in the same conditions is formed as one pure $(S, S)$-enantiomer.

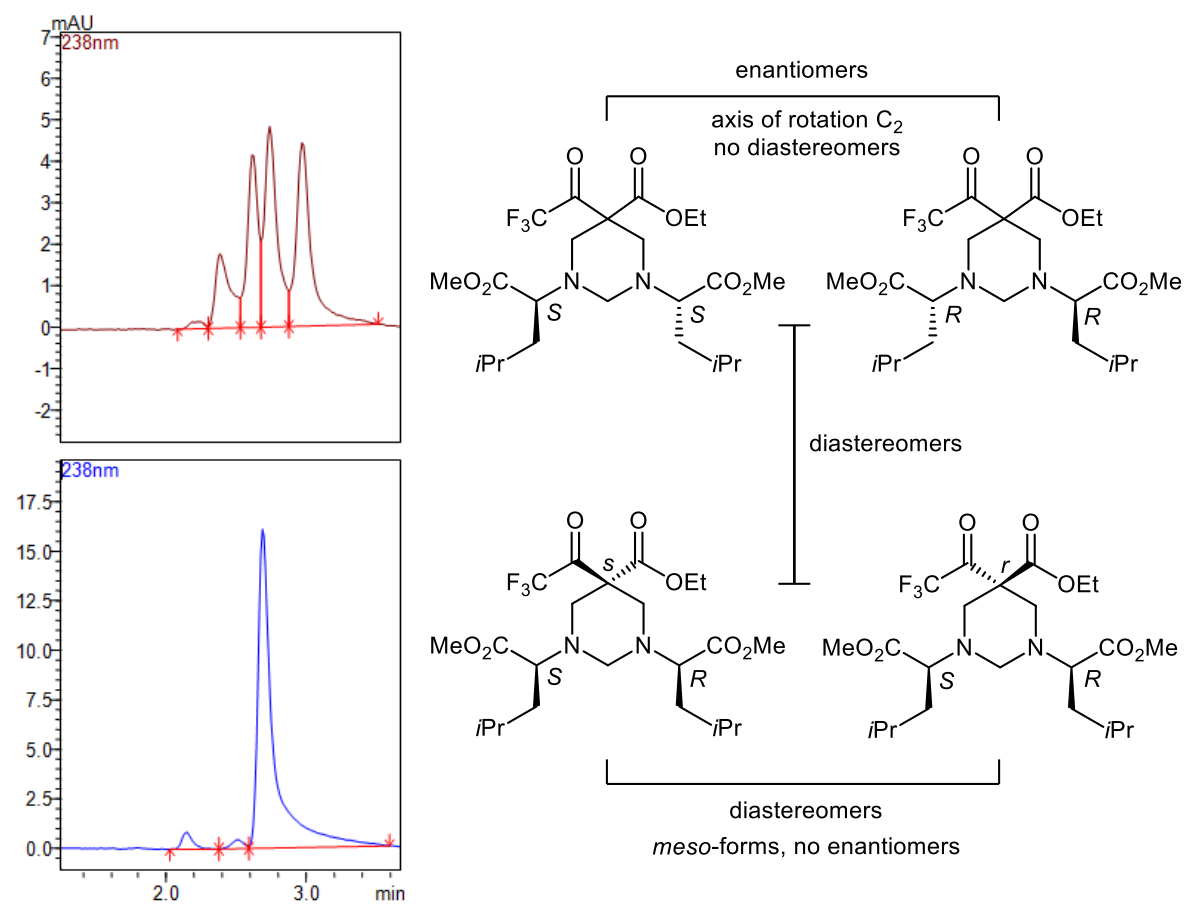

Figure 1. Four stereoisomers of compound $\mathbf{4} \mathbf{d}$ formed in the reaction of racemic leucine methyl ester and chiral HPLC analysis for them (top) in comparison with the same enantiopure (bottom).

The reaction of 1,1,1-trifluoropentane-2,4-dione (1b) with formaldehyde and ethyl glycinate hydrochloride (2a), similarly to keto ester $\mathbf{1 a}$ under the same conditions, gives 1,3,5-trisubstituted hexahydropyrimidine $\mathbf{3 f}$ containing no trifluoroacetyl group (Table 1, entry 6). However, if the $\mathrm{CH}$-acid : $\mathrm{CH}_{2} \mathrm{O}$ : amino ester molar ratio is changed from $1: 15: 2$ to $1: 4: 2$, the reaction occurs with retention of the trifluoroacetyl group to give hexahydropyrimidine $\mathbf{4 f}$ in $70 \%$ yield (entry 7 ). It might seem that the reaction of diketone $\mathbf{1 b}$ with formaldehyde and ethyl (S)-tyrosinate hydrochloride (2f) under the same conditions would have to result in a hexahydropyrimidine with retention of the trifluoroacetyl moiety. However, only deacylated product $\mathbf{3 g}$ was 
found after the reaction (entry 8). It cannot be ruled out that this reaction pathway, unlike with the similar amino esters $\mathbf{2 c}-\mathbf{e}$, is favored by the presence of weakly acidic phenol moieties in the amino ester component.

A study of the effect of time on the reaction completeness showed that hexahydropyrimidines were mostly formed in the first several hours. In fact, the yields of compound $3 f$ in 1, 7 and $24 \mathrm{~h}$ are 30,39 and $42 \%$, respectively, and almost does not increase after that. An increase in the amount of acetate buffer or addition of dichloromethane ( $c a$. 5-fold) in order to increase the solubility of the components favors the homogenization of the reaction mixture but has little effect on the yields of hexahydropyrimidines. The reaction carried out in water, diethyl ether, acetic acid, or in methanol under reflux conditions gave complex mixtures of compounds in which no hexahydropyrimidine derivatives were found.

On switching to 1,1,1,5,5,5-hexafluoropentane-2,4-dione (1c), an abrupt decrease in the yields of hexahydropyrimidines was observed; moreover, only one trifluoroacetyl group (or its hydrate form) remained in the reaction products. In fact, diketone 1c entered a Mannich reaction with 33\% aqueous formaldehyde and ethyl glycinate hydrochloride at a $\mathrm{CH}$-acid : $\mathrm{CH}_{2} \mathrm{O}$ : amino ester molar ratio of $1: 15: 2$ to give two trifluoromethyl-containing hexahydropyrimidines 5 a and 6 in a total yield of 30\% in $1: 1$ ratio (Table 2). By decreasing the amount of formaldehyde (molar ratio $1 \mathbf{c}: \mathrm{CH}_{2} \mathrm{O}: \mathbf{2 a}=1: 4: 2$ ), we succeeded to obtain the hexahydropyrimidine 6 selectively, but its yield increased insignificantly (to only 18\%).

Under similar conditions (Table 2, Entry 3), ethyl (S)-tyrosinate hydrochloride (2f) as the amine component gave 5 -trifluoroacetylhexahydropyrimidine $\mathbf{5 f}$ in $45 \%$ yield. Previously, ${ }^{18}$ the possibility of involving $1,3-$ diketones containing two trifluoromethyl groups in the Mannich reaction was denied entirely due to formation of stable tetraols or bis-hemiketals in alcoholic or aqueous media. It is interesting to note that at molar ratio $1 \mathbf{c}: \mathrm{CH}_{2} \mathrm{O}: \mathbf{2 f}=1: 15: 2$ no compounds containing the hexahydropyrimidine frame were isolated.

Table 2. Synthesis of fluorinated hexahydropyrimidines 5 and $\mathbf{6}$

\begin{tabular}{cccccc} 
Entry & Molar ratio 1c: $\mathrm{CH}_{2} \mathrm{O}: \mathbf{2}$ & & Amino ester & Isolated yields (\%) \\
\hline 1 & $1: 15: 2$ & $\mathbf{2 a}$ & $\mathrm{R}=\mathrm{H}$ & $\mathbf{5 a}(15)$ & $\mathbf{6}(15)$ \\
2 & $1: 4: 2$ & $\mathbf{2 a}$ & $\mathrm{R}=\mathrm{H}$ & $\mathbf{6}(18)$ \\
3 & $1: 4: 2$ & $\mathbf{2 f}$ & $\mathrm{R}=\mathrm{CH}_{2} \mathrm{C}_{6} \mathrm{H}_{4} \mathrm{OH}-4$ & $\mathbf{5 f}(45)$ & - \\
\hline
\end{tabular}

Unlike with diketones $\mathbf{1} \mathbf{b}, \mathbf{c}$, a somewhat unexpected result was obtained in the reaction of keto ester $\mathbf{1 a}$ with ethyl (S)-tyrosinate hydrochloride (2f) in the presence of a 15 -fold molar excess of $\mathrm{CH}_{2} \mathrm{O}$. In this case we obtained chiral tetrahydropyrimidinium salt 7 containing the trifluoroacetate anion (Scheme 2). This compound was isolated in $63 \%$ yield by column chromatography on $\mathrm{SiO}_{2}$ as a crystalline compound with m.p. $77-78^{\circ} \mathrm{C} ;{ }^{19}$ none of the expected hexahydropyrimidines was found. 


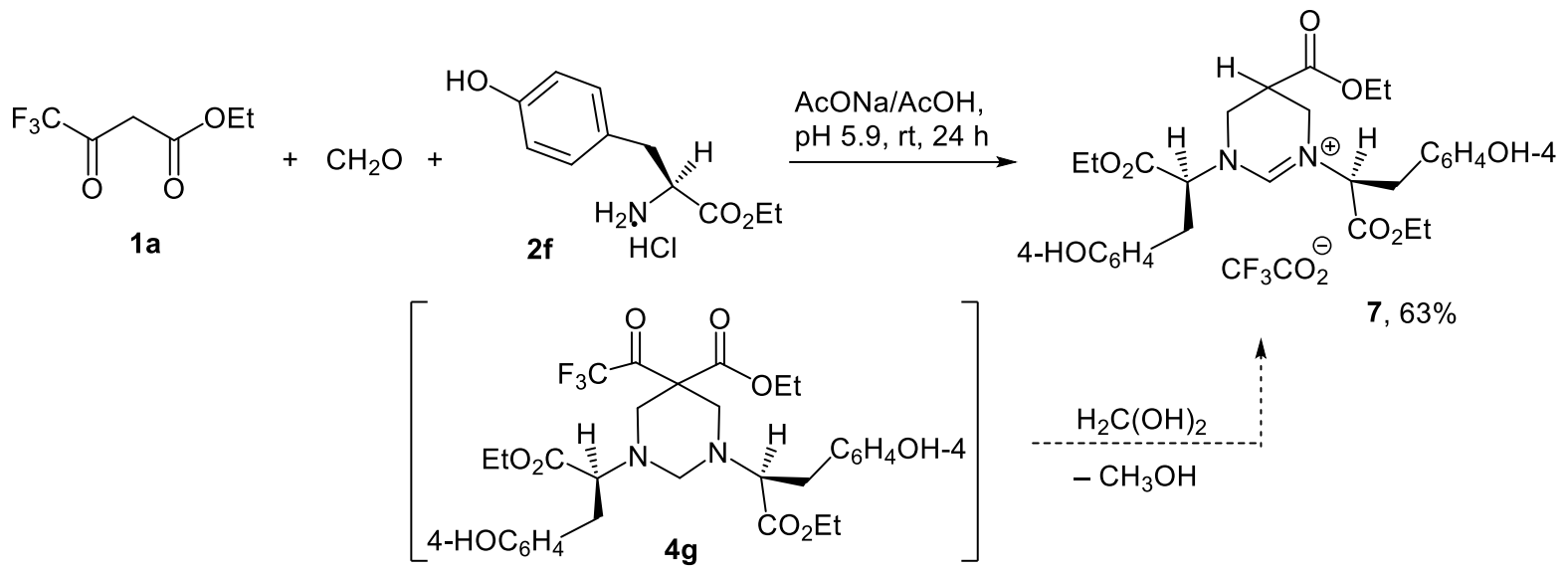

Scheme 2. Preparation of tetrahydropyrimidinium salt $\mathbf{7}$ using $(S)$-tyrosine derivative $\mathbf{2 f}$.

A specific feature of this reaction is that the formation of the tetrahydropyrimidinium moiety assumes that a redox process occurs, where one of the formaldehyde molecules acts as the oxidant and is converted to methanol. Formally, the overall result of this transformation corresponds to the cleavage of the prospective compound $\mathbf{4 g}$ under the action of the hydrated formaldehyde (Scheme 2), but how this actually happens we cannot yet explain. Tetrahydropyrimidinium salts are generally obtained either by quaternization of tetrahydropyrimidines or by dehydrogenation of hexahydropyrimidines. ${ }^{20}$ There are no data in literature on one-pot methods for the synthesis of structures of this kind from simple linear starting compounds.

Though salt 7 forms good crystals, we failed to obtain an X-ray analysis. Nevertheless, its structure was totally confirmed by ${ }^{1} \mathrm{H},{ }^{13} \mathrm{C},{ }^{15} \mathrm{~N}$, and ${ }^{19} \mathrm{~F} N \mathrm{NM}$ spectroscopy with the use of $2 \mathrm{D}$ techniques and gradient pulse sequences, viz., COSY, TOCSY, NOESY, DOSY, HSQC, HMBC, ${ }^{15} \mathrm{~N}-\mathrm{HMBC},{ }^{19} \mathrm{~F}-\mathrm{HMBC}$ and ${ }^{19} \mathrm{~F}-\mathrm{HOESY}$, and the data completely match the ionic form described.

This is also confirmed by HRMS ESI data (in positive mode) that directly show that the cation of this salt is present. It was found that in solution, the trifluoroacetate anion is rather strongly bound with the cation into an ion pair. The 2D ${ }^{1} \mathrm{H},{ }^{19} \mathrm{~F}-\mathrm{HOESY} N M R$ spectra in $\mathrm{CDCl}_{3}$ solution show ${ }^{1} \mathrm{H}-{ }^{19} \mathrm{~F}$ heteronuclear NOE couplings between the $\mathrm{CF}_{3}$ group and the protons of aromatic rings, showing that they are rather close in space (Figure 2).

Aside from the unusual formation of an ionic structure itself, salt $\mathbf{7}$ behaves in a very interesting manner in solutions with various polarities. In low-polar solvents $\left(\mathrm{CDCl}_{3}\right)$, compound $\mathbf{7}$ forms stable associates that strongly affect NMR spectra (Figure 3). In fact, the NOE sign changes from positive to negative, which occurs if the molecular mass of the solution structural unit increases above $1000 \mathrm{Da}$. Furthermore, due to the formation of associates, the diffusion coefficient in the solution decreases significantly. (The diffusion coefficient was measured using 2D ${ }^{1} \mathrm{H}$ DOSY NMR spectra, Diffusion Ordered NMR Spectroscopy). It is very difficult to judge on the structure of these associates. Perhaps, they are formed through intermolecular interaction of trifluoroacetate anions with cations that link them into a long chain. The trifluoroacetate anion in $\mathrm{CDCl}_{3}$ solution is rather strongly bound with the cation into ion pairs and is quite close to it in space, which results in ${ }^{1} \mathrm{H}-{ }^{19} \mathrm{~F}$ Heteronuclear NOE coupling in $2 \mathrm{D}^{1} \mathrm{H},{ }^{19} \mathrm{~F}-\mathrm{HOESY}$ NMR spectra (Figure 2 ). 


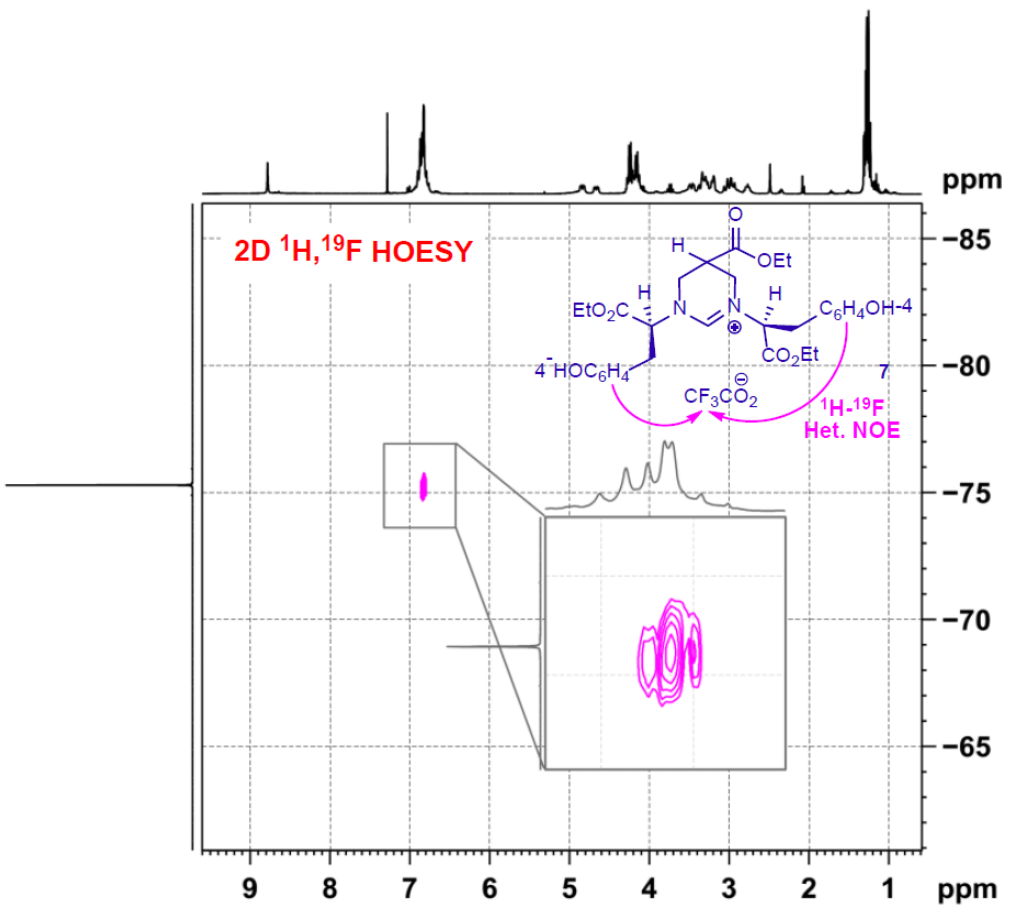

Figure 2. The $2 \mathrm{D}^{1} \mathrm{H},{ }^{19} \mathrm{~F}$ HOESY NMR spectrum (mixing time $2 \mathrm{sec}$ ) of salt 7 in $\mathrm{CDCl}_{3}$. Enlarged aromatic region of the spectrum is given in the rectangle. ${ }^{1} \mathrm{H}-{ }^{19} \mathrm{~F}$ Heteronuclear NOE correlations are shown in crimson color on the spectrum and by corresponding arrows on the structure.

In more polar solvents $\left(\mathrm{CD}_{3} \mathrm{CN}\right)$ the associates decompose and compound 7 behaves as an ordinary lowmolecular compound. In NMR spectra, the NOE sign becomes positive, while the diffusion coefficient increases considerably. Furthermore, the chemical shifts change strongly in comparison with the solution in $\mathrm{CDCl}_{3}$.
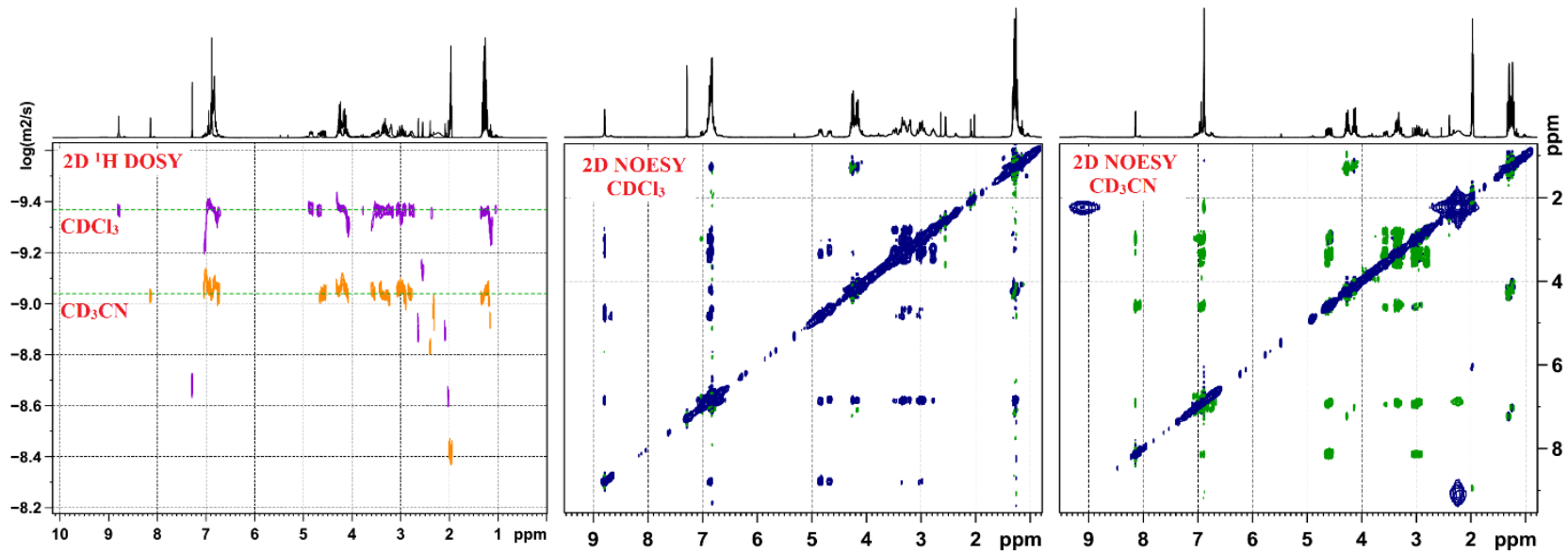

Figure 3. The left image: two imposed 2D ${ }^{1} \mathrm{H}$ LED-DOSY NMR spectra of salt 7 in $\mathrm{CDCl}_{3}$ (purple) and $\mathrm{CD}_{3} \mathrm{CN}$ (orange); green dashed lines indicate the approximate diffusion coefficients of salt 7; the associates of $\mathbf{7}$ in $\mathrm{CDCl}_{3}$ have higher $\mathrm{MW}$ and lower diffusion coefficients. The central and right images: $2 \mathrm{D}{ }^{1} \mathrm{H},{ }^{1} \mathrm{H}$ NOESY NMR spectra (mixing time $1 \mathrm{sec}$ ) of salt 7 in $\mathrm{CDCl}_{3}$ (the central image) and $\mathrm{CD}_{3} \mathrm{CN}$ (the right image); the color the of cross-peaks indicates the sign of the NOE effect (green - positive, blue - negative); in $\mathrm{CDCl}_{3}$ all cross-peaks have a negative sign (abnormal for low molecular weight compounds) which indicates the formation of associates. 
The chemical shift $\delta_{\mathrm{H}}$ of the $\mathrm{N}-\mathrm{CH}=\mathrm{N}^{+}$signal changes most significantly (by $0.7 \mathrm{ppm}$, i.e., from 8.8 to 8.1 ). In this case, addition of just a few drops of $\mathrm{CD}_{3} \mathrm{CN}$ to a solution in $\mathrm{CDCl}_{3}$ decomposes the associates to a considerable extent. This apparently occurs due to stabilization of ion pairs by molecules of the polar solvent with formation of a solvate shell.

The formation of associates is demonstrated in the pictures showing the 2D NOESY and 2D DOSY NMR spectra (Figure 3). In fact, two pictures of $2 \mathrm{D}$ NOESY in $\mathrm{CDCl}_{3}$ and $\mathrm{CD}_{3} \mathrm{CN}$ demonstrate the NOE sign change (Figure 3, the central and right images; the sign is shown by cross-peaks, green - positive, blue - negative, relative to the diagonal which is always negative; all the signals change their sign). The change in the diffusion coefficients is demonstrated by the $2 \mathrm{D}{ }^{1} \mathrm{H}$ DOSY NMR spectra superimposed on the same scale (Figure 3, the left image; the logarithm of the diffusion coefficient changes from -9.03 in $\mathrm{CD}_{3} \mathrm{CN}$ (orange) to -9.37 in $\mathrm{CDCl}_{3}$ (purple)).

\section{Conclusions}

We have studied the reaction of fluorine-containing 1,3-dicarbonyl compounds (ethyl 3-oxo-4,4,4trifluorobutanoate (1a), 1,1,1-trifluoropentane-2,4-dione (1b) and 1,1,1,5,5,5-hexafluoropentane-2,4-dione (1c)) with formaldehyde and esters of natural amino acids under Mannich reaction conditions. New derivatives of 1,3,5- and 1,3,5,5-substituted hexahydropyrimidines have been obtained, including those with a trifluoroacetyl group at position 5 of the heterocycle. These compounds show promise as ligands for asymmetric metal-complex catalysis and as chiral synthons for the preparation of biologically active compounds with a broad spectrum of activity. A one-pot method for the synthesis of a new chiral tetrahydropyrimidinium salt, based on the reaction of ethyl 3-oxo-4,4,4-trifluorobutanoate with ethyl (S)tyrosinate and excess formaldehyde at a $1: 2: 15$ molar ratio of the components in acetate buffer medium (pH 5.9) at room temperature, is suggested.

\section{Experimental Section}

General. ${ }^{1} \mathrm{H}$ and ${ }^{13} \mathrm{C}$ NMR spectra were recorded on a Bruker $\mathrm{AM}-300$ (300.1 and $75.5 \mathrm{MHz}$, respectively) or Bruker Avance-III 500 (500 and $125 \mathrm{MHz}$, respectively) spectrometers with TMS as internal standard at $25^{\circ} \mathrm{C}$. ${ }^{19} \mathrm{~F}$ NMR spectra were obtained using a Bruker Avance-III 500 spectrometer $(470 \mathrm{MHz})$ with $\mathrm{CFCl}_{3}$ as external standard. The mass spectra were obtained on a Shimadzu LC-MS-2010EV liquid chromatograph-mass spectrometer in the chemical ionization mode at atmospheric pressure and on a MaXis (Bruker Daltonics) mass spectrometer in the chemical ionization mode. The melting points were determined on a Boetius melting point apparatus. Elemental analysis were performed with a CHNS Euro EA 3000 Elemental Analyzer. Optical rotations were determined with a Perkin Elmer 341 polarimeter $(\lambda 589 \mathrm{~nm})$ at $20^{\circ} \mathrm{C}$. TLC analyses were carried out using Sorbfil plates PTSKh-AF-A plates (IMID Ltd.); eluent chloroform-methanol (9:1) or petroleum etherEtOAc (7:3). Kieselgel 60 Macherey-Nagel (140-270 mesh) was used for column chromatography (gradient elution with chloroform-methanol from 0 to $10 \%$ of the latter or petroleum ether-EtOAc from 0 to $30 \%$ of the latter). All reagents were purchased from commercial sources and used without further purification, unless otherwise indicated. 
Reaction of trifluoromethyl 1,3-dicarbonyl compounds with formaldehyde and $\alpha$-amino esters; General Procedure. To a solution of the appropriate amino ester hydrochloride $2 \mathrm{a}-\mathrm{f}(5.4 \mathrm{mmol})$ in acetate buffer $(\mathrm{pH}$ 5.9) $(1.5 \mathrm{~mL})$ trifluoromethyl 1,3-dicarbonyl compound $1 \mathrm{a}-\mathrm{c}(2.7 \mathrm{mmol})$ and formaldehyde $33 \%$ aqueous solution (11 or $40 \mathrm{mmol}$ ) were added. The resulting mixture was stirred for $24 \mathrm{~h}$ at room temperature, then it was extracted with $\mathrm{CH}_{2} \mathrm{Cl}_{2}(3 \times 10 \mathrm{~mL})$ and the combined organic layers were dried over $\mathrm{Na}_{2} \mathrm{SO}_{4}$ and evaporated in vacuo. The product was purified by column chromatography on Kieselgel 60 (chloroform-MeOH 10:0 $\rightarrow 9: 1$ or hexane-EtOAc 10:0 $\rightarrow 7: 3)$.

Ethyl 1,3-bis(2-ethoxy-2-oxoethyl)hexahydropyrimidine-5-carboxylate (3a). Yield $0.55 \mathrm{~g}$ (62\%); colorless oil; $\mathrm{R}_{f}=0.38\left(\mathrm{CH}_{2} \mathrm{Cl}_{2}\right.$-EtOAc, 7:3). ${ }^{1} \mathrm{H}$ NMR $\left(500 \mathrm{MHz}, \mathrm{CDCl}_{3}\right): \delta=1.25\left(\mathrm{t}, J 7.1 \mathrm{~Hz}, 3 \mathrm{H}, \mathrm{CH}_{3}\right), 1.28(\mathrm{t}, J 7.1 \mathrm{~Hz}, 6 \mathrm{H}$, $\mathrm{CH}_{3}$ ), $2.88\left(\mathrm{dd}, J 12.5\right.$ and $\left.10.8 \mathrm{~Hz}, 2 \mathrm{H}, \mathrm{CH}_{2}{ }^{(\mathrm{a})} \mathrm{N}\right), 3.05(\mathrm{tt}, J 10.8$ and $4.2 \mathrm{~Hz}, 1 \mathrm{H}, \mathrm{CH}$ ), 3.31 (ddd, J 12.5, 4.2 and $\left.1.5 \mathrm{~Hz}, 2 \mathrm{H}, \mathrm{CH}_{2}{ }^{(\mathrm{e})} \mathrm{N}\right), 3.43\left(\mathrm{~d}, J 17.1 \mathrm{~Hz}, 2 \mathrm{H}, \mathrm{NCH}_{2} \mathrm{CO}_{2}\right), 3.58\left(\mathrm{~d}, J 17.1 \mathrm{~Hz}, 2 \mathrm{H}, \mathrm{NCH}_{2} \mathrm{CO}_{2}\right), 3.63(\mathrm{~d}, J 10.8 \mathrm{~Hz}, 1 \mathrm{H}$, $\left.\mathrm{NCH}_{2}{ }^{(\mathrm{a})} \mathrm{N}\right), 3.96\left(\mathrm{dt}, J 10.8 \mathrm{~Hz}\right.$ and $\left.1.5 \mathrm{~Hz}, 1 \mathrm{H}, \mathrm{NCH}_{2}{ }^{(\mathrm{e})} \mathrm{N}\right), 4.14\left(q, J 7.1 \mathrm{~Hz}, 2 \mathrm{H}, \mathrm{CHCO}_{2} \mathrm{CH}_{2}\right), 4.19(\mathrm{q}, J 7.1 \mathrm{~Hz}, 4 \mathrm{H}$, $\left.\mathrm{OCH}_{2}\right) .{ }^{13} \mathrm{C}$ NMR $\left(125 \mathrm{MHz}, \mathrm{CDCl}_{3}\right): \delta=14.15,14.16,36.96,52.68,54.68,60.98,61.04,72.55,169.71,171.36$. ${ }^{15} \mathrm{~N} \mathrm{NMR}\left(50 \mathrm{MHz}, \mathrm{CDCl}_{3}\right): \delta=36.65$. MS (ESI): $\mathrm{m} / z 331[\mathrm{M}+\mathrm{H}]^{+}\left(\mathrm{C}_{15} \mathrm{H}_{27} \mathrm{~N}_{2} \mathrm{O}_{6}\right), 353[\mathrm{M}+\mathrm{Na}]^{+}\left(\mathrm{C}_{15} \mathrm{H}_{26} \mathrm{~N}_{2} \mathrm{NaO}_{6}\right)$. Anal. Calcd. for $\mathrm{C}_{15} \mathrm{H}_{26} \mathrm{~N}_{2} \mathrm{O}_{6}: \mathrm{C}, 54.53 ; \mathrm{H}, 7.93 ; \mathrm{N}, 8.48$. Found: $\mathrm{C}, 54.48 ; \mathrm{H}, 7.87 ; \mathrm{N}, 8.47 \%$.

Ethyl 1,3-bis(2-methoxy-1-methyl-2-oxoethyl)hexahydropyrimidine-5-carboxylate (3b). Yield $0.50 \mathrm{~g}(56 \%)$; colorless oil; $\mathrm{R}_{f}=0.4\left(\mathrm{CH}_{2} \mathrm{Cl}_{2}-\mathrm{EtOAc}, 7: 3\right) ;[\alpha]_{\mathrm{D}}^{20}-34.1 \pm 0.1$ (c 1, $\left.\mathrm{CHCl}_{3}\right) .{ }^{1} \mathrm{H} \mathrm{NMR}\left(500 \mathrm{MHz}, \mathrm{CDCl}_{3}\right): \delta=1.26(\mathrm{t}, J$ $7.1 \mathrm{~Hz}, 3 \mathrm{H}, \mathrm{CO}_{2} \mathrm{CH}_{2} \mathrm{C}_{3}$, ), 1.34 (d, J $7.1 \mathrm{~Hz}, 6 \mathrm{H}, \mathrm{CHCH}_{3}$ ), 2.68 (dd, J 11.8 and $10.8 \mathrm{~Hz}, 1 \mathrm{H}, \mathrm{CH}_{2}{ }^{(\mathrm{a})} \mathrm{N}$ ), 2.75 (dd, J 11.8 and $\left.10.8 \mathrm{~Hz}, 1 \mathrm{H}, \mathrm{CH}_{2}{ }^{(\mathrm{a})} \mathrm{N}\right), 2.86(\mathrm{tt}, J 10.8$ and $4.3 \mathrm{~Hz}, 1 \mathrm{H}, \mathrm{CH}), 3.14$ (ddt, J 11.8, $4.3 \mathrm{~Hz}$ and $1.5 \mathrm{~Hz}, 1 \mathrm{H}$, $\left.\mathrm{CH}_{2}{ }^{(\mathrm{e})} \mathrm{N}\right), 3.26\left(\mathrm{ddt}, J 11.8,4.3\right.$ and $\left.1.5 \mathrm{~Hz}, 1 \mathrm{H}, \mathrm{CH}_{2}{ }^{(\mathrm{e})} \mathrm{N}\right), 3.41\left(\mathrm{~d}, J 10.7 \mathrm{~Hz}, 1 \mathrm{H}, \mathrm{NCH}_{2}{ }^{(\mathrm{a})} \mathrm{N}\right), 3.50(\mathrm{q}, J 7.1 \mathrm{~Hz}, 1 \mathrm{H}$, $\left.\mathrm{CHCH}_{3}\right), 3.58\left(\mathrm{q}, J 7.1 \mathrm{~Hz}, 1 \mathrm{H}, \mathrm{CHCH}_{3}\right), 3.71\left(\mathrm{~s}, 6 \mathrm{H}, \mathrm{OCH}_{3}\right), 3.76\left(\mathrm{dt}, J 10.7\right.$, and $\left.1.5 \mathrm{~Hz}, 1 \mathrm{H}, \mathrm{NCH}_{2}^{(\mathrm{e})} \mathrm{N}\right), 4.13(\mathrm{q}, J$ $\left.7.1 \mathrm{~Hz}, 2 \mathrm{H}, \mathrm{OCH}_{2}\right) .{ }^{13} \mathrm{C} \mathrm{NMR}\left(125 \mathrm{MHz}, \mathrm{CDCl}_{3}\right): \delta=14.19,15.25,15.43,38.76,48.88,51.59,51.63,59.26,59.85$, $60.65,68.55,172.15,173.44,173.66 .{ }^{15} \mathrm{~N} \mathrm{NMR}\left(50 \mathrm{MHz}, \mathrm{CDCl}_{3}\right): \delta=46.64,47.81 . \mathrm{MS}(\mathrm{ESI}): \mathrm{m} / z 331[\mathrm{M}+\mathrm{H}]^{+}$ $\left(\mathrm{C}_{15} \mathrm{H}_{27} \mathrm{~N}_{2} \mathrm{O}_{6}\right)$. Anal. Calcd. for $\mathrm{C}_{15} \mathrm{H}_{26} \mathrm{~N}_{2} \mathrm{O}_{6}: \mathrm{C}, 54.53 ; \mathrm{H}, 7.93 ; \mathrm{N}, 8.48$. Found: $\mathrm{C}, 54.51 ; \mathrm{H}, 7.87 ; \mathrm{N}, 8.48 \%$.

Ethyl 1,3-bis[1-(methoxycarbonyl)-2-methylpropyl]hexahydropyrimidine-5-carboxylate (3c). Yield $0.13 \mathrm{~g}$ (10\%); colorless oil; $\mathrm{R}_{f}=0.56$ (hexane-EtOAc, 7:3). ${ }^{1} \mathrm{H}$ NMR $\left(500 \mathrm{MHz}, \mathrm{CDCl}_{3}\right): \delta=0.86\left(\mathrm{~d}, J 6.5 \mathrm{~Hz}, 3 \mathrm{H}, \mathrm{CHCH}_{3}\right)$, 0.87 (d, J $6.5 \mathrm{~Hz}, 3 \mathrm{H}, \mathrm{CHC}_{3}$ ), 0.96 (d, J $\left.6.5 \mathrm{~Hz}, 3 \mathrm{H}, \mathrm{CHC}_{3}\right), 0.98$ (d, J $\left.6.5 \mathrm{~Hz}, 3 \mathrm{H}, \mathrm{CHC}_{3}\right), 1.25(\mathrm{t}, J 7.1 \mathrm{~Hz}, 3 \mathrm{H}$, $\left.\mathrm{OCH}_{2} \mathrm{CH}_{3}\right), 2.02\left(\mathrm{~m}, 1 \mathrm{H}, \underline{\mathrm{C}}\left(\mathrm{CH}_{3}\right)_{2}\right), 2.07\left(\mathrm{~m}, 1 \mathrm{H}, \underline{\mathrm{CH}}\left(\mathrm{CH}_{3}\right)_{2}\right), 2.55\left(\mathrm{~m}, 1 \mathrm{H}, \mathrm{CH}_{2}{ }^{(\mathrm{a})} \mathrm{N}\right), 2.79\left(\mathrm{~m}, 1 \mathrm{H}, \mathrm{CH}_{2}{ }^{(\mathrm{a})} \mathrm{N}\right), 2.80(\mathrm{~m}$, $\left.1 \mathrm{H}, \mathrm{CH}_{\mathbf{C}} \mathrm{CO}_{2} \mathrm{CH}_{2} \mathrm{CH}_{3}\right), 2.86\left(\mathrm{~d}, J 14.2 \mathrm{~Hz}, 1 \mathrm{H}, \mathrm{C} \underline{\mathrm{HCH}}\left(\mathrm{CH}_{3}\right)_{2}\right), 2.93\left(\mathrm{~d}, J 9.9 \mathrm{~Hz}, 1 \mathrm{H}, \mathrm{C} \underline{\mathrm{H}} \mathrm{CH}\left(\mathrm{CH}_{3}\right)_{2}\right), 2.99(\mathrm{~m}, 1 \mathrm{H}$, $\left.\mathrm{CH}_{2}{ }^{(\mathrm{e})} \mathrm{N}\right), 3.07\left(\mathrm{~m}, 1 \mathrm{H}, \mathrm{CH}_{2}{ }^{(\mathrm{e})} \mathrm{N}\right), 3.27\left(\mathrm{~d}, J 10.4 \mathrm{~Hz}, 1 \mathrm{H}, \mathrm{NCH}_{2}{ }^{(\mathrm{a})} \mathrm{N}\right), 3.51\left(\mathrm{dt}, J 10.4\right.$ and $\left.1.5 \mathrm{~Hz}, 1 \mathrm{H}, \mathrm{NCH}_{2}{ }^{(\mathrm{e})} \mathrm{N}\right), 3.72$ $\left(\mathrm{s}, 3 \mathrm{H}, \mathrm{OCH}_{3}\right), 3.73\left(\mathrm{~s}, 3 \mathrm{H}, \mathrm{OCH}_{3}\right), 4.12$ (q, J $\left.7.1 \mathrm{~Hz}, 2 \mathrm{H}, \mathrm{OCH}_{2}\right) .{ }^{13} \mathrm{C} \mathrm{NMR}\left(125 \mathrm{MHz}_{\mathrm{CDCl}}\right): \delta=14.21,19.07$, 19.30, 19.43, 19.49, 26.94, 27.23, 39.45, 49.22, 50.84, 50.99, 51.03, 60.50, 70.46, 71.77, 72.07, 171.83, 172.45, 172.68. ${ }^{15} \mathrm{~N}$ NMR $\left(50 \mathrm{MHz}, \mathrm{CDCl}_{3}\right): \delta=43.60$. MS (ESI): $\mathrm{m} / z 385[\mathrm{M}+\mathrm{H}]^{+}\left(\mathrm{C}_{19} \mathrm{H}_{35} \mathrm{~N}_{2} \mathrm{O}_{6}\right), 409[\mathrm{M}+\mathrm{Na}]^{+}$ $\left(\mathrm{C}_{19} \mathrm{H}_{34} \mathrm{~N}_{2} \mathrm{NaO}_{6}\right)$. Anal. Calcd. for $\mathrm{C}_{19} \mathrm{H}_{34} \mathrm{~N}_{2} \mathrm{O}_{6}$ : C, 59.05; $\mathrm{H}, 8.87 ; \mathrm{N}, 7.25$. Found: $\mathrm{C}, 58.98 ; \mathrm{H}, 8.79 ; \mathrm{N}, 7.24,44.62$ $\%$.

Ethyl 1,3-bis[1-(methoxycarbonyl)-2-methylpropyl]-5-(trifluoroacethyl)hexahydropyrimidine-5-carboxylate (4c). Yield $0.62 \mathrm{~g}\left(48 \%\right.$ ); colorless oil; $[\alpha]_{\mathrm{D}}^{20}-34.6 \pm 0.1$ (c 1, $\mathrm{CHCl}_{3}$ ); $\mathrm{R}_{f}=0.36$ (hexane-EtOAc, 7:3). ${ }^{1} \mathrm{H} \mathrm{NMR}(500$ $\mathrm{MHz}, \mathrm{CDCl}_{3}$ ): $\delta=0.85$ (d, $3 \mathrm{H}, J 6.5 \mathrm{~Hz}, \mathrm{CHC}_{3}$ ), 0.86 (d, J $\left.6.5 \mathrm{~Hz}, 3 \mathrm{H}, \mathrm{CHCH}_{3}\right), 0.88$ (d, J $\left.6.5 \mathrm{~Hz}, 3 \mathrm{H}, \mathrm{CHC}_{3}\right), 1.06$ (d, J $\left.6.5 \mathrm{~Hz}, 3 \mathrm{H}, \mathrm{CHCH}_{3}\right), 1.23\left(\mathrm{t}, J 7.1 \mathrm{~Hz}, 3 \mathrm{H}, \mathrm{OCH}_{2} \underline{\mathrm{C}}_{3}\right), 2.03\left(\mathrm{~m}, 1 \mathrm{H}, \mathrm{C} \underline{\mathrm{H}}\left(\mathrm{CH}_{3}\right)_{2}\right), 2.09\left(\mathrm{~m}, 1 \mathrm{H}, \mathrm{C} \underline{\mathrm{H}}\left(\mathrm{CH}_{3}\right)_{2}\right), 2.66(\mathrm{~d}$, J $\left.11.8 \mathrm{~Hz}, 1 \mathrm{H}, \mathrm{CH}_{2}{ }^{(\mathrm{a})} \mathrm{N}\right), 2.75(\mathrm{~d}, J 14.2 \mathrm{~Hz}, 1 \mathrm{H}, \mathrm{NCH}), 2.77(\mathrm{~d}, J 14.2 \mathrm{~Hz}, 1 \mathrm{H}, \mathrm{NCH}), 3.01\left(\mathrm{~d}, J 12.7 \mathrm{~Hz}, 1 \mathrm{H}, \mathrm{CH}_{2}{ }^{(\mathrm{a})} \mathrm{N}\right)$, $3.07\left(\mathrm{~d}, J 9.2 \mathrm{~Hz}, 1 \mathrm{H}, \mathrm{NCH}_{2}{ }^{(\mathrm{a})} \mathrm{N}\right), 3.46\left(\mathrm{dt}, J 12.7\right.$ and $\left.1.5 \mathrm{~Hz}, 1 \mathrm{H}, \mathrm{CH}_{2}{ }^{(\mathrm{e})} \mathrm{N}\right), 3.59\left(\mathrm{dt}, J 9.2\right.$ and $\left.1.5 \mathrm{~Hz}, 1 \mathrm{H}, \mathrm{NCH}{ }^{(\mathrm{e})} \mathrm{N}\right)$, $3.62\left(\mathrm{dt}, J 11.8\right.$ and $\left.1.5 \mathrm{~Hz}, 1 \mathrm{H}, \mathrm{CH}_{2}{ }^{(\mathrm{e})} \mathrm{N}\right), 3.69\left(\mathrm{~s}, 3 \mathrm{H}, \mathrm{OCH}_{3}\right), 3.71\left(\mathrm{~s}, 3 \mathrm{H}, \mathrm{OCH}_{3}\right), 4.15\left(\mathrm{q}, J 7.1 \mathrm{~Hz}, 2 \mathrm{H}, \mathrm{OCH}_{2}\right) .{ }^{13} \mathrm{C}$ NMR $\left(125 \mathrm{MHz}_{\mathrm{CDCl}}\right): \delta=13.80,18.68,19.54,19.61,19.80,27.13,27.14,50.38,50.90,51.07,54.74,57.64$, 
62.48, 69.36, 72.66, 72.83, $115.70\left(\mathrm{q},{ }^{1} \mathrm{~J}_{\mathrm{C}, \mathrm{F}}=294.2 \mathrm{~Hz}, \mathrm{CF}_{3}\right), 166.78,171.49,173.65,185.76\left(\mathrm{q},{ }^{2} \mathrm{~J}_{\mathrm{C}, \mathrm{F}}=33.8 \mathrm{~Hz}\right.$, $\left.\mathrm{COCF}_{3}\right) \cdot{ }^{15} \mathrm{~N} \mathrm{NMR}\left(50 \mathrm{MHz}, \mathrm{CDCl}_{3}\right): \delta=41.02,43.12 .{ }^{19} \mathrm{~F} \mathrm{NMR}\left(470 \mathrm{MHz}, \mathrm{CDCl}_{3}\right): \delta=-73.05 . \mathrm{MS}(\mathrm{ESI}): \mathrm{m} / z 505$ $[\mathrm{M}+\mathrm{Na}]^{+}\left(\mathrm{C}_{21} \mathrm{H}_{33} \mathrm{~F}_{3} \mathrm{~N}_{2} \mathrm{NaO}_{7}\right)$. Anal. Calcd. for $\mathrm{C}_{21} \mathrm{H}_{33} \mathrm{~F}_{3} \mathrm{~N}_{2} \mathrm{O}_{7}$ : C, 52.28; $\mathrm{H}, 6.89 ; \mathrm{N}, 5.81$. Found: $\mathrm{C}, 52.22 ; \mathrm{H}, 6.83$; $\mathrm{N}, 5.80 \%$.

Ethyl 1,3-bis[1-(methoxycarbonyl)-2-methylbuthyl]hexahydropyrimidine-5-carboxylate (3d). Yield $0.36 \mathrm{~g}$ (26\%); colorless oil; $\mathrm{R}_{f}=0.65$ (hexane-EtOAc, 7:3). ${ }^{1} \mathrm{H}$ NMR $\left(300 \mathrm{MHz}, \mathrm{CDCl}_{3}\right): \delta=0.89\left(\mathrm{~d}, J 6.0 \mathrm{~Hz}, 6 \mathrm{H}, \mathrm{CHC} \mathrm{H}_{3}\right)$, 0.94 (d, J $\left.6.0 \mathrm{~Hz}, 6 \mathrm{H}, \mathrm{CHCH}_{3}\right), 1.22$ (t, J $\left.7.1 \mathrm{~Hz}, 3 \mathrm{H}, \mathrm{OCH}_{2} \mathrm{C}_{3}{ }_{3}\right), 1.57\left(\mathrm{~m}, 2 \mathrm{H}, \mathrm{NCHC}_{2}\right), 1.64\left(\mathrm{~m}, 2 \mathrm{H}, \mathrm{NCHC} \underline{H}_{2}\right), 1.64$ $\left(\mathrm{m}, 2 \mathrm{H}, \mathrm{C} \underline{\mathrm{H}}\left(\mathrm{CH}_{3}\right)_{2}\right), 2.83\left(\mathrm{~d}, J 10.9 \mathrm{~Hz}, 1 \mathrm{H}, \mathrm{CH}_{2} \mathrm{~N}\right), 3.10\left(\mathrm{~d}, J 12.3 \mathrm{~Hz}, 1 \mathrm{H}, \mathrm{CH}_{2} \mathrm{~N}\right), 3.28\left(\mathrm{~d}, J 9.0 \mathrm{~Hz}, 1 \mathrm{H}, \mathrm{NCH}{ }_{2} \mathrm{~N}\right)$, 3.32 (t, J $7.1 \mathrm{~Hz}, 1 \mathrm{H}, \mathrm{NCH}), 3.37(\mathrm{t}, J 7.1,1 \mathrm{H}, \mathrm{NCH}), 3.41(\mathrm{~m}, 1 \mathrm{H}, \mathrm{CH}), 3.50\left(\mathrm{~m}, 1 \mathrm{H}, \mathrm{CH}_{2} \mathrm{~N}\right), 3.64(\mathrm{~d}, J 12.4 \mathrm{~Hz}, 1 \mathrm{H}$, $\mathrm{CH}_{2} \mathrm{~N}$ ), $3.66\left(\mathrm{~d}, J 9.0 \mathrm{~Hz}, 1 \mathrm{H}, \mathrm{NCH}_{2} \mathrm{~N}\right), 3.70\left(\mathrm{~s}, 6 \mathrm{H}, \mathrm{CO}_{2} \mathrm{CH}_{3}\right), 4.18$ (q, J 7.1, 2H, $\left.\mathrm{OCH}_{2}\right) .{ }^{13} \mathrm{C} \mathrm{NMR}\left(125 \mathrm{MHz}^{\mathrm{CDCl}} \mathrm{CD}_{3}\right)$ $\delta=14.09,21.94,22.14,22.47,22.80,24.78,25.00,38.09,38.53,39.34,48.80,51.09,51.21,51.66,60.46$, 62.85, 63.33, 69.21, 172.20, 172.77, 173.16. MS (ESI): $m / z 413.3[\mathrm{M}-\mathrm{H}]^{+}\left(\mathrm{C}_{21} \mathrm{H}_{37} \mathrm{~N}_{2} \mathrm{O}_{6}\right)$. Anal. Calcd. for $\mathrm{C}_{23} \mathrm{H}_{38} \mathrm{~N}_{2} \mathrm{O}_{7}$ : C, 60.85; $\mathrm{H}, 9.24 ; \mathrm{N}, 6.76$. Found: $\mathrm{C}, 60.97 ; \mathrm{H}, 9.22 ; \mathrm{N}, 6.81 \%$.

Ethyl 1,3-bis[1-(methoxycarbonyl)-2-methylbuthyl]-5-(trifluoroacethyl)hexahydropyrimidine-5-carboxylate (4d). Yield $0.55 \mathrm{~g}$ (40\%); colorless oil; $[\alpha]_{\mathrm{D}}^{20}-28.5 \pm 0.1$ (c 1, $\mathrm{CHCl}_{3}$ ); $\mathrm{R}_{f}=0.78$ (hexane-EtOAc, 7:3). ${ }^{1} \mathrm{H} \mathrm{NMR}(500$ $\mathrm{MHz}_{\mathrm{CDCl}}$ ): $\delta=0.88\left(\mathrm{~d}, J 6.4 \mathrm{~Hz}, 3 \mathrm{H}, \mathrm{CHC}_{3}\right.$ ) $, 0.88\left(\mathrm{~d}, J 6.4 \mathrm{~Hz}, 3 \mathrm{H}, \mathrm{CHC}_{3}\right), 0.89\left(\mathrm{~d}, J 6.4 \mathrm{~Hz}, 3 \mathrm{H}, \mathrm{CHC} \underline{H}_{3}\right), 0.94$ (d, J $\left.6.4 \mathrm{~Hz}, 3 \mathrm{H}, \mathrm{CHC}_{3}\right), 1.24\left(\mathrm{t}, J 7.1 \mathrm{~Hz}, 3 \mathrm{H}, \mathrm{OCH}_{2} \underline{\mathrm{C}}_{3}\right), 1.55\left(\mathrm{~m}, 2 \mathrm{H}, \mathrm{NCHC} \underline{H}_{2}\right), 1.61\left(\mathrm{~m}, 2 \mathrm{H}, \mathrm{NCHC} \underline{H}_{2}\right), 1.65(\mathrm{~m}$, $\left.1 \mathrm{H}, \underline{\mathrm{C}}\left(\mathrm{CH}_{3}\right)_{2}\right), 1.67\left(\mathrm{~m}, 1 \mathrm{H}, \mathrm{C} \underline{\mathrm{H}}\left(\mathrm{CH}_{3}\right)_{2}\right), 2.82\left(\mathrm{~d}, J 12.0 \mathrm{~Hz}, 1 \mathrm{H}, \mathrm{CH}_{2}{ }^{(\mathrm{a})} \mathrm{N}\right), 3.11\left(\mathrm{~d}, J 12.3 \mathrm{~Hz}, 1 \mathrm{H}, \mathrm{CH}_{2}{ }^{(\mathrm{a})} \mathrm{N}\right), 3.27(\mathrm{~d}, J$ $\left.8.8 \mathrm{~Hz}, 1 \mathrm{H}, \mathrm{NCH}_{2}{ }^{(\mathrm{a})} \mathrm{N}\right), 3.33(\mathrm{t}, J 7.6 \mathrm{~Hz}, 1 \mathrm{H}, \mathrm{NCH}), 3.35(\mathrm{t}, J 7.6 \mathrm{~Hz}, 1 \mathrm{H}, \mathrm{NCH}), 3.50\left(\mathrm{~d}, J 12.3 \mathrm{~Hz}, 1 \mathrm{H}, \mathrm{CH}_{2}{ }^{(\mathrm{e})} \mathrm{N}\right), 3.64$ (d, J $\left.12.0 \mathrm{~Hz}, 1 \mathrm{H}, \mathrm{CH}_{2}{ }^{(\mathrm{e})} \mathrm{N}\right), 3.65\left(\mathrm{~d}, J 8.8 \mathrm{~Hz}, 1 \mathrm{H}, \mathrm{NCH}_{2}{ }^{(\mathrm{e})} \mathrm{N}\right), 3.69\left(\mathrm{~s}, 6 \mathrm{H}, \mathrm{CO}_{2} \mathrm{CH}_{3}\right), 4.20$ (q, J 7.1 Hz, $\left.2 \mathrm{H}, \mathrm{OCH}_{2}\right) .{ }^{13} \mathrm{C}$ NMR $\left(125 \mathrm{MHz}, \mathrm{CDCl}_{3}\right): \delta=13.80,22.04,22.33,22.53,22.71,24.45,24.76,37.88,37.95,50.03,51.26,51.34$, $54.23,57.67,62.48,63.56,63.67,68.67,115.68\left(q,{ }^{1} J_{C, F}=293.7 \mathrm{~Hz}, C F_{3}\right), 166.83,172.51,172.57,186.06\left(q, J_{C, F}\right.$ $\left.=33.9 \mathrm{~Hz}, \underline{C O C F}_{3}\right) . \mathrm{MS}(\mathrm{ESI}): \mathrm{m} / \mathrm{z} 511[\mathrm{M}+\mathrm{H}]^{+}\left(\mathrm{C}_{21} \mathrm{H}_{38} \mathrm{~F}_{3} \mathrm{~N}_{2} \mathrm{O}_{6}\right)$. Anal. Calcd. for $\mathrm{C}_{23} \mathrm{H}_{37} \mathrm{~F}_{3} \mathrm{~N}_{2} \mathrm{O}_{7}: \mathrm{C}, 54.11 ; \mathrm{H}, 7.30$; $\mathrm{N}, 5.49$. Found: $\mathrm{C}, 54.05 ; \mathrm{H}, 7.22 ; \mathrm{N}, 5.46 \%$.

Ethyl 1,3-bis(1-benzyl-2-ethoxy-2-oxoethyl)-5-(trifluoroacethyl)hexahydropyrimidine-5-carboxylate (4e). Yield $0.76 \mathrm{~g}$ (46\%); colorless oil; $[\alpha]_{\mathrm{D}}^{20}-30.8 \pm 0.1$ (c 1, $\mathrm{CHCl}_{3}$ ); $\mathrm{R}_{f}=0.71$ (hexane-EtOAc, 7:3). ${ }^{1} \mathrm{H} \mathrm{NMR}(300 \mathrm{MHz}$, $\left.\mathrm{CDCl}_{3}\right): \delta=1.17\left(\mathrm{t}, J 7.1 \mathrm{~Hz}, 3 \mathrm{H}, \mathrm{CO}_{2} \mathrm{CH}_{2} \mathrm{C}_{3}\right), 1.24\left(\mathrm{t}, J 7.1 \mathrm{~Hz}, 6 \mathrm{H}, \mathrm{CHCO}_{2} \mathrm{CH}_{2} \mathrm{C}_{3}\right.$ ), $2.92\left(\mathrm{~d}, J 13.4 \mathrm{~Hz}, 2 \mathrm{H}, \mathrm{C}_{2} \mathrm{Ph}\right)$, 3.06 (dd, J 13.4 and $\left.3.1 \mathrm{~Hz}, 2 \mathrm{H}, \mathrm{C}_{2} \mathrm{Ph}\right), 3.15\left(\mathrm{~d}, J 11.8 \mathrm{~Hz}, 1 \mathrm{H}, \mathrm{CH}_{2}{ }^{(\mathrm{a})} \mathrm{N}\right), 3.30\left(\mathrm{~d}, J 9.1 \mathrm{~Hz}, 1 \mathrm{H}, \mathrm{NCH}_{2}{ }^{(\mathrm{a})} \mathrm{N}\right), 3.47(\mathrm{~d}, J$ $\left.10.2 \mathrm{~Hz}, 1 \mathrm{H}, \mathrm{CH}_{2}{ }^{(\mathrm{a})} \mathrm{N}\right), 3.56\left(\mathrm{~d}, J 10.2 \mathrm{~Hz}, 1 \mathrm{H}, \mathrm{CH}_{2}{ }^{(\mathrm{e})} \mathrm{N}\right), 3.81\left(\mathrm{~d}, J 11.8 \mathrm{~Hz}, 1 \mathrm{H}, \mathrm{CH}_{2}{ }^{(\mathrm{e})} \mathrm{N}\right), 3.89(\mathrm{~d}, J 9.1 \mathrm{~Hz}, 1 \mathrm{H}$, $\left.\mathrm{NCH}_{2}{ }^{(\mathrm{e})} \mathrm{N}\right), 4.09\left(\mathrm{q}, J 7.1 \mathrm{~Hz}, 2 \mathrm{H}, \mathrm{OCH}_{2}\right), 4.02(\mathrm{~m}, 2 \mathrm{H}, \mathrm{NCH}), 4.18\left(\mathrm{t}, J 7.1 \mathrm{~Hz}, 4 \mathrm{H}, \mathrm{CHCO}_{2} \mathrm{CH}_{2}\right), 7.12-7.31(\mathrm{~m}, 10 \mathrm{H}$, $\mathrm{CH}(\mathrm{Ar})) .{ }^{13} \mathrm{C}$ NMR $\left(75 \mathrm{MHz}, \mathrm{CDCl}_{3}\right): \delta=13.77,14.25,35.64,35.75,50.61,54.38,57.68,60.34,60.49,62.52$, $67.46,67.77,69.33,115.52\left(\mathrm{q},{ }^{1}{ }_{\mathrm{C}, \mathrm{F}}=294.1 \mathrm{~Hz}, \mathrm{CF}_{3}\right), 126.56,128.34,128.40,137.47,137.60,166.62,170.57$, 170.67, 185.80 (q, $\left.\underline{C O C F}_{3},{ }^{2} J_{C, F}=33.7 \mathrm{~Hz}\right)$. MS (ESI): $\mathrm{m} / z 607[\mathrm{M}+\mathrm{H}]^{+}\left(\mathrm{C}_{31} \mathrm{H}_{38} \mathrm{~F}_{3} \mathrm{~N}_{2} \mathrm{O}_{7}\right)$. Anal. Calcd. for $\mathrm{C}_{31} \mathrm{H}_{37} \mathrm{~F}_{3} \mathrm{~N}_{2} \mathrm{O}_{7}$ : C, 61.38; $\mathrm{H}, 6.15 ; \mathrm{N}, 4.62$. Found: $\mathrm{C}, 61.33 ; \mathrm{H}, 6.11 ; \mathrm{N}, 4.62 \%$.

Diethyl 5-acetylhexahydropyrimidine-1,3-diacetate (3f). Yield $0.34 \mathrm{~g}$ (42\%); dark orange oil; $\mathrm{R}_{f}=0.3$ (hexaneEtOAc, 7:3). ${ }^{1} \mathrm{H}$ NMR (300 MHz, $\left.\mathrm{CDCl}_{3}\right): \delta=1.26\left(\mathrm{t}, J 7.0 \mathrm{~Hz}, 6 \mathrm{H}, \mathrm{OCH}_{2} \mathrm{CH}_{3}\right), 2.03\left(\mathrm{~s}, 3 \mathrm{H}, \mathrm{OCH}_{3}\right), 3.09(\mathrm{t}, J 11.3 \mathrm{~Hz}$, $2 \mathrm{H}, \mathrm{CH}_{2} \mathrm{~N}$ ), 2.97 (td, J 10.4 and $3.5 \mathrm{~Hz}, 1 \mathrm{H}, \mathrm{CH}$ ), 3.14 (d, J $\left.12.3 \mathrm{~Hz}, 2 \mathrm{H}, \mathrm{CH}_{2} \mathrm{~N}\right), 3.28\left(\mathrm{~d}, J 17.0 \mathrm{~Hz}, 2 \mathrm{H}, \mathrm{NC}_{2} \mathrm{CO}_{2}\right.$ ), $3.43\left(\mathrm{~d}, J 17.0 \mathrm{~Hz}, 2 \mathrm{H}, \mathrm{NCH}_{2} \mathrm{CO}_{2}\right.$ ), 3.71 (d, J $10.5 \mathrm{~Hz}, 2 \mathrm{H}, \mathrm{NCH}_{2} \mathrm{~N}$ ), 4.12 (q, J 7.1 Hz, 4H, $\left.\mathrm{COCH}_{2}\right) .{ }^{13} \mathrm{C} \mathrm{NMR}(125$ $\left.\left.\mathrm{MHz}, \mathrm{CDCl}_{3}\right): \delta=14.08,28.58,44.94,52.69\right), 55.06,60.70,72.95,170.15,207.83$. Anal. Calcd. for $\mathrm{C}_{16} \mathrm{H}_{24} \mathrm{~N}_{2} \mathrm{O}_{6}$ : C, 55.98; H, 8.05; N, 9.33. Found: C, 56.04; H, 8.06; N, $9.35 \%$.

Diethyl 5-acetyl-5-trifluoroacetylhexahydropyrimidine-1,3-diacetate (4f). Yield $0.75 \mathrm{~g}(70 \%) ;$ red oil; $\mathrm{R}_{f}=0.2$ (hexane-EtOAc, 7:3). ${ }^{1} \mathrm{H}$ NMR $\left(500 \mathrm{MHz}_{\mathrm{CDCl}}\right.$ ): $\delta=1.27\left(\mathrm{t}, J 7.1 \mathrm{~Hz}, 3 \mathrm{H}, \mathrm{OCH}_{2} \mathrm{CH}_{3}\right), 1.28(\mathrm{t}, J 7.1 \mathrm{~Hz}, 3 \mathrm{H}$, $\mathrm{OCH}_{2} \mathrm{C}_{3}$ ), 2.07 (s, 3H, OCH$)_{3}, 3.09$ (dd, J 12.5 and $3.6 \mathrm{~Hz}, 2 \mathrm{H}, \mathrm{CH}_{2} \mathrm{~N}$ ), 3.44 (dd, J 12.8 and $3.6 \mathrm{~Hz}, 2 \mathrm{H}, \mathrm{CH}_{2} \mathrm{~N}$ ), 
3.61 (d, J $17.2 \mathrm{~Hz}, 2 \mathrm{H}, \mathrm{NC}_{2} \mathrm{CO}_{2}$ ), 3.73 (d, J $17.2 \mathrm{~Hz}, 2 \mathrm{H}, \mathrm{NC}_{2} \mathrm{CO}_{2}$ ), 3.85 (d, J $\left.10.4 \mathrm{~Hz}, 1 \mathrm{H}, \mathrm{NCH}_{2}{ }^{(\mathrm{a})} \mathrm{N}\right), 3.92(\mathrm{~d}, J$ $\left.10.4 \mathrm{~Hz}, 1 \mathrm{H}, \mathrm{NCH}_{2}{ }^{(\mathrm{e})} \mathrm{N}\right), 4.19$ (q, J $\left.7.1 \mathrm{~Hz}, 2 \mathrm{H}, \mathrm{OCH}_{2}\right), 4.20$ (q, J 7.1 Hz, $\left.2 \mathrm{H}, \mathrm{OCH}_{2}\right) .{ }^{13} \mathrm{C} \mathrm{NMR}\left(125 \mathrm{MHz}, \mathrm{CDCl}_{3}\right): \delta=$ 14.10, 14.16, 24.96, 44.35, 51.48, 53.69, 62.05, 76.58, 118.12 (q, $\left.{ }^{1} J_{C, F}=290 \mathrm{~Hz}, \mathrm{CF}_{3}\right), 168.23\left(\mathrm{CO}_{2}\right), 175.92(\mathrm{q}$,

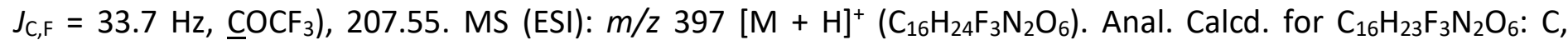
48.48; H, 5.85; N, 7.07. Found: C, 48.55; H, 5.82; N, $7.08 \%$.

5-Acetyl-1,3-bis[(2-ethoxy-1-(4-hydroxybenzyl)-2-oxoethyl)]hexahydropyrimidine (3g). Yield $0.64 \mathrm{~g}$ (46\%); red-orange solid; $\mathrm{mp} 60-61{ }^{\circ} \mathrm{C}$ (decomp.); $[\alpha]_{\mathrm{D}}^{20}-28.7 \pm 0.1$ (c $\left.1, \mathrm{CHCl}_{3}\right) ; \mathrm{R}_{f}=0.67\left(\mathrm{CH}_{2} \mathrm{Cl}_{2}-\mathrm{MeOH}, 9: 1\right) .{ }^{1} \mathrm{H} \mathrm{NMR}$ $\left(500 \mathrm{MHz}, \mathrm{CDCl}_{3}\right): \delta=1.15\left(\mathrm{t}, J 7.1 \mathrm{~Hz}, 3 \mathrm{H}, \mathrm{CH}_{3}\right), 1.18\left(\mathrm{t}, J 7.1 \mathrm{~Hz}, 3 \mathrm{H}, \mathrm{CH}_{3}\right), 2.07\left(\mathrm{~s}, 3 \mathrm{H}, \mathrm{OCH}_{3}\right), 2.61(\mathrm{t}, J 10.8 \mathrm{~Hz}$, $\left.1 \mathrm{H}, \mathrm{CH}_{2} \mathrm{~N}\right), 2.81\left(\mathrm{~d}, J 8.4 \mathrm{~Hz}, 4 \mathrm{H}, \mathrm{C}_{2} \mathrm{Ar}\right), 2.89(\mathrm{~m}, 1 \mathrm{H}, \mathrm{CH}), 2.92\left(\mathrm{~m}, 1 \mathrm{H}, \mathrm{CH}_{2} \mathrm{~N}\right), 3.02\left(\mathrm{~d}, J 9.2 \mathrm{~Hz}, 1 \mathrm{H}, \mathrm{CH}_{2} \mathrm{~N}\right), 3.29$ (d, J $9.2 \mathrm{~Hz}, 1 \mathrm{H}, \mathrm{CH}_{2} \mathrm{~N}$ ), $3.48\left(\mathrm{~d}, J 10.4 \mathrm{~Hz}, 1 \mathrm{H}, \mathrm{NCH}_{2}{ }^{(\mathrm{a})} \mathrm{N}\right), 3.55\left(\mathrm{t}, J 7.8 \mathrm{~Hz}, 2 \mathrm{H}, \mathrm{NCHCO}_{2}\right), 3.49(\mathrm{t}, J 7.8 \mathrm{~Hz}, 2 \mathrm{H}$, $\mathrm{NCH} \mathrm{HO}_{2}$ ), $3.79\left(\mathrm{~d}, J 10.4 \mathrm{~Hz}, 1 \mathrm{H}, \mathrm{NCH}_{2}{ }^{(\mathrm{e})} \mathrm{N}\right), 4.08\left(\mathrm{q}, J 7.1 \mathrm{~Hz}, 2 \mathrm{H}, \mathrm{OCH}_{2}\right), 4.12\left(\mathrm{q}, J 7.1 \mathrm{~Hz}, 2 \mathrm{H}, 0 \mathrm{OCH}_{2}\right), 6.62-7.05$ (m, 10H, CH(Ar)). ${ }^{13} \mathrm{C}$ NMR (125 MHz, CDCl $): \delta=14.25,14.40,28.66,34.47,35.27,46.40,49.15,51.61,60.70$, $60.79,66.89,67.16,69.79,115.45,128.85,129.47,130.31,154.81,171.65,172.25,209.17 . \mathrm{HRMS}-\mathrm{ESI}: \mathrm{m} / z$ [M $+\mathrm{H}]^{+}$calcd for $\mathrm{C}_{28} \mathrm{H}_{36} \mathrm{~N}_{2} \mathrm{O}_{7}$ : 513.2595; found 513.2604.

1,3-Bis(2-ethoxy-2-oxoethyl)-5-(trifluoroacetyl)hexahydropyrimidine (5a). Yield $144 \mathrm{mg}$ (15\%); colorless solid; mp 93-95 ${ }^{\circ} \mathrm{C} ; \mathrm{R}_{f}=0.24$ (hexane-EtOAc, 7:3). ${ }^{1} \mathrm{H} \mathrm{NMR}\left(500 \mathrm{MHz}, \mathrm{CDCl}_{3}\right): \delta=1.28\left(\mathrm{t}, J 7.1 \mathrm{~Hz}, 6 \mathrm{H}, \mathrm{CH}_{3}\right), 2.84(\mathrm{~m}$, $\left.2 \mathrm{H}, \mathrm{CH}_{2} \mathrm{~N}\right), 3.21\left(\mathrm{~m}, 2 \mathrm{H}, \mathrm{CH}_{2} \mathrm{~N}\right), 3.33\left(\mathrm{~d}, J 17.0 \mathrm{~Hz}, 2 \mathrm{H}, \mathrm{CH}_{2} \mathrm{CO}_{2}\right), 3.38\left(\mathrm{~d}, J 8.0 \mathrm{~Hz}, 1 \mathrm{H}, \mathrm{NCH}_{2} \mathrm{~N}\right), 3.48(\mathrm{~d}, J 17.0 \mathrm{~Hz}$, $\left.2 \mathrm{H}, \mathrm{CH}_{2} \mathrm{CO}_{2}\right), 3.49(\mathrm{~m}, 1 \mathrm{H}, \mathrm{CH}), 3.75\left(\mathrm{~d}, J 8.0 \mathrm{~Hz}, 1 \mathrm{H}, \mathrm{NCH}_{2} \mathrm{~N}\right), 4.19\left(\mathrm{q}, J 7.1 \mathrm{~Hz}, 4 \mathrm{H}, \mathrm{OCH}_{2}\right) .{ }^{13} \mathrm{C} \mathrm{NMR}(125 \mathrm{MHz}$, $\left.\mathrm{CDCl}_{3}\right): \delta=14.22,40.08,52.23,52.57,54.88,60.89,72.64,115.39\left(\mathrm{q},{ }^{1} J_{\mathrm{C}, \mathrm{F}}=292 \mathrm{~Hz}, \mathrm{CF}_{3}\right), 170.28,190.84\left(\mathrm{q},{ }^{2} J_{\mathrm{C}, \mathrm{F}}\right.$ $\left.=34 \mathrm{~Hz}, \underline{\mathrm{COCF}}_{3}\right) .{ }^{19} \mathrm{~F} \mathrm{NMR}\left(470 \mathrm{MHz}, \mathrm{CDCl}_{3}\right): \delta=-78.10$. HRMS-ESI: $\mathrm{m} / z[\mathrm{M}+\mathrm{H}]^{+}$calcd for $\mathrm{C}_{14} \mathrm{H}_{22} \mathrm{~F}_{3} \mathrm{~N}_{2} \mathrm{O}_{5}$ : 355.1475 ; found 355.1472 .

1,3-Bis(2-ethoxy-2-oxoethyl)-5-(2,2,2-trifluoro-1,1-dihydroxy)hexahydropyrimidine (6). Yield $0.13 \mathrm{~g}$ (12\%); white solid; $\mathrm{Mp} \mathrm{61-62}{ }^{\circ} \mathrm{C} ; \mathrm{R}_{f}=0.22$ (hexane-EtOAc, 7:3). ${ }^{1} \mathrm{H}$ NMR $\left(500 \mathrm{MHz}, \mathrm{CDCl}_{3}\right): \delta=1.28(\mathrm{t}, J 7.1 \mathrm{~Hz}, 6 \mathrm{H}$, $\left.\mathrm{CH}_{3}\right), 2.22(\mathrm{~m}, 1 \mathrm{H}, \mathrm{CH}), 2.50\left(\mathrm{~m}, 2 \mathrm{H}, \mathrm{CH}_{2} \mathrm{~N}\right), 3.18$ (d, J $\left.17.0 \mathrm{~Hz}, 2 \mathrm{H}, \mathrm{NCH}_{2} \mathrm{CO}_{2}\right), 3.24\left(\mathrm{~d}, J 8.0 \mathrm{~Hz}, 1 \mathrm{H}, \mathrm{NCH}_{2} \mathrm{~N}\right), 3.30$ (d, J $17.0 \mathrm{~Hz}, 2 \mathrm{H}, \mathrm{NCH}_{2} \mathrm{CO}_{2}$ ), $3.36\left(\mathrm{~m}, 2 \mathrm{H}, \mathrm{CH}_{2} \mathrm{~N} \text { ), } 3.76 \text { (d, J } 8.0 \mathrm{~Hz}, 1 \mathrm{H}, \mathrm{NCH}_{2} \mathrm{~N} \text { ), } 4.20 \text { (q, J 7.1 Hz, 4H, OCH }\right)_{2}, 6.80$ (br.s $2 \mathrm{H}, \mathrm{OH}) .{ }^{13} \mathrm{C} \mathrm{NMR}\left(125 \mathrm{MHz}, \mathrm{CDCl}_{3}\right): \delta=14.15,35.51,52.30,52.59,55.63,61.36,74.36,94.71\left(\mathrm{q},{ }^{2} \mathrm{~J}_{\mathrm{C}, \mathrm{F}}=28\right.$ $\left.\mathrm{Hz}, \mathrm{CF}_{3} \underline{\mathrm{C}}(\mathrm{OH})_{2}\right), 123.89\left(\mathrm{q},{ }^{1} \mathrm{~J}_{\mathrm{C}, \mathrm{F}}=287 \mathrm{~Hz}, \mathrm{CF}_{3}\right), 170.03 .{ }^{19} \mathrm{~F} \mathrm{NMR}\left(470 \mathrm{MHz}, \mathrm{CDCl}_{3}\right): \delta=-85.59 . \mathrm{HRMS}-\mathrm{ESI}: \mathrm{m} / \mathrm{z}$ [M $+\mathrm{H}]^{+}$calcd for $\mathrm{C}_{14} \mathrm{H}_{24} \mathrm{~F}_{3} \mathrm{~N}_{2} \mathrm{O}_{6}: 373.1581$; found 373.1578 .

1,3-Bis[2-ethoxy-1-(4-hydroxybenzyl)-2-oxoethyl]-5-(trifluoroacethyl)hexahydropyrimidine (5f). Yield $0.69 \mathrm{~g}$ (45\%); colorless solid; mp 63-65 ${ }^{\circ} \mathrm{C} ; \mathrm{R}_{f}=0.78\left(\mathrm{CH}_{2} \mathrm{Cl}_{2}-\mathrm{MeOH}, 9: 1\right) .{ }^{1} \mathrm{H} \mathrm{NMR}\left(500 \mathrm{MHz}, \mathrm{CDCl}_{3}\right): \delta=1.12(\mathrm{t}, J 7.0$ $\left.\mathrm{Hz}, 3 \mathrm{H}, \mathrm{CH}_{3}\right), 1.15\left(\mathrm{t}, J 7.0 \mathrm{~Hz}, 3 \mathrm{H}, \mathrm{CH}_{3}\right), 2.73-2.79\left(\mathrm{~m}, 1 \mathrm{H}, \mathrm{CH}_{2} \mathrm{~N}\right), 2.79-2.98\left(\mathrm{~m}, 4 \mathrm{H}, \mathrm{CH}_{2} \mathrm{Ar}\right), 2.85-2.94(\mathrm{~m}, 1 \mathrm{H}$, $\left.\mathrm{CH}_{2} \mathrm{~N}\right), 3.12-3.18\left(\mathrm{~m}, 1 \mathrm{H}, \mathrm{CH}_{2} \mathrm{~N}\right), 3.35-3.45\left(\mathrm{~m}, 1 \mathrm{H}, \mathrm{CH}_{2} \mathrm{~N}\right), 3.39-3.46(\mathrm{~m}, 1 \mathrm{H}, \mathrm{CH}), 3.42-3.59\left(\mathrm{~m}, 2 \mathrm{H}, \mathrm{NCHCO}_{2}\right)$, 3.54-3.59 (m, 1H, NCH $2 \mathrm{~N}), 3.89\left(\mathrm{~d}, J 10.8 \mathrm{~Hz}, 1 \mathrm{H}, \mathrm{NCH}_{2} \mathrm{~N}\right), 4.02\left(\mathrm{q}, J 7.0 \mathrm{~Hz}, 2 \mathrm{H}, \mathrm{OCH}_{2}\right), 4.09(\mathrm{q}, J 7.0 \mathrm{~Hz}, 2 \mathrm{H}$, $\left.\mathrm{OCH}_{2}\right), 6.61-6.75(\mathrm{~m}, 4 \mathrm{H}, 0-\mathrm{Ar}), 6.81-7.05$ (m, 4H, $\left.\mathrm{M}-\mathrm{Ar}\right) .{ }^{13} \mathrm{C} \mathrm{NMR}\left(125 \mathrm{MHz}, \mathrm{CDCl}_{3}\right): \delta=14.17,14.27,34.54$, 40.86, 48.24, 51.28, 61.15, 66.82, 69.39, 115.57 (q, $\left.{ }^{1} J_{C, F}=292 \mathrm{~Hz}, \mathrm{CF}_{3}\right), 129.09,130.20,130.45,154.75,171.63$, 172.23, $189.23\left(\mathrm{q},{ }^{2} \mathrm{~J}_{\mathrm{C}, \mathrm{F}}=35.3 \mathrm{~Hz}, \underline{\mathrm{COCF}_{3}}\right) . \mathrm{MS}(\mathrm{ESI}): \mathrm{m} / z 567[\mathrm{M}+\mathrm{H}]^{+}\left(\mathrm{C}_{28} \mathrm{H}_{34} \mathrm{~F}_{3} \mathrm{~N}_{2} \mathrm{O}_{7}\right)$.

5-Ethoxycarbonyl-1,3-bis[2-ethoxy-1-(4-hydroxybenzyl)-2-oxoethyl]-3,4,5,6-tetrahydropyrimidin-1-ium trifluoroacetate (7). Yield $1.12 \mathrm{~g}(63 \%) ;$ pale yellow solid; $\mathrm{mp} 77-78{ }^{\circ} \mathrm{C} ; \mathrm{R}_{f}=0.22\left(\mathrm{CH}_{2} \mathrm{Cl}_{2}-\mathrm{MeOH}, 9.5: 0.5\right) .{ }^{1} \mathrm{H}$ NMR $\left(500 \mathrm{MHz}, \mathrm{CDCl}_{3}\right): \delta=1.24\left(\mathrm{t}, J 7.1 \mathrm{~Hz}, 3 \mathrm{H}, \mathrm{CCO}_{2} \mathrm{CH}_{2} \mathrm{C}_{3}\right), 1.27\left(\mathrm{t}, J 7.1 \mathrm{~Hz}, 3 \mathrm{H}, \mathrm{CO}_{2} \mathrm{CH}_{2} \mathrm{C}_{3}\right), 1.30$ (t, J 7.1 $\mathrm{Hz}, 3 \mathrm{H}, \mathrm{CO}_{2} \mathrm{CH}_{2} \mathrm{CH}_{3}$ ), 2.88 (quintet, J $7.5 \mathrm{~Hz}, 1 \mathrm{H}, \mathrm{CH}$ ), 2.97 (dd, J $14.5 \mathrm{~Hz}, J 10.6 \mathrm{~Hz}, 1 \mathrm{H}, \mathrm{CH}_{2}{ }^{\mathrm{A}} \mathrm{Ar}$ ), 3.08 (dd, J 14.9 and $11.1 \mathrm{~Hz}, 1 \mathrm{H}, \mathrm{CH}_{2}{ }^{\mathrm{B}} \mathrm{Ar}$ ), 3.34 (ddd, J 14.1, 5.0 and $1.5 \mathrm{~Hz}, 1 \mathrm{H}, \mathrm{CH}_{2} \mathrm{~N}$ ), 3.34 (dd, J 14.5 and $5.4 \mathrm{~Hz}, 1 \mathrm{H}, \underline{\mathrm{C}}_{2}{ }^{\mathrm{B}} \mathrm{Ar}$ ), 3.35 (dd, J 14.9 and $5.1 \mathrm{~Hz}, 1 \mathrm{H}, \mathrm{CH}_{2}{ }^{\mathrm{B} A r}$ ), 3.45 (dd, J 14.1 and $7.5 \mathrm{~Hz}, 1 \mathrm{H}, \mathrm{CH}_{2}{ }^{(\mathrm{a})} \mathrm{N}$ ), 3.46 (dd, J 14.1 and $7.5 \mathrm{~Hz}$, $\left.1 \mathrm{H}, \mathrm{CH}_{2}{ }^{(\mathrm{a})} \mathrm{N}\right), 3.64$ (ddd, J 14.1, 5.0 and $\left.1.5 \mathrm{~Hz}, 1 \mathrm{H}, \mathrm{CH}_{2}{ }^{(\mathrm{e})} \mathrm{N}\right), 4.13\left(\mathrm{q}, J 7.1 \mathrm{~Hz}, 2 \mathrm{H}, \mathrm{CCO}_{2} \mathrm{C}_{2}\right.$ ), 4.24 and 4.26 (both 
q, J $7.1 \mathrm{~Hz}, 2 \times 2 \mathrm{H}, \mathrm{OCH}_{2}$ ), 4.67 (dd, J 10.6 and $\left.5.4 \mathrm{~Hz}, 1 \mathrm{H}, \mathrm{NCH}\right), 4.79$ (dd, J 11.1 and $\left.5.1 \mathrm{~Hz}, 1 \mathrm{H}, \mathrm{NCH}\right), 6.76(\mathrm{~d}, J$ $8.5 \mathrm{~Hz}, 2 \mathrm{H}, \mathrm{M}-\mathrm{Ar}$ ), 6.79 (d, J $8.5 \mathrm{~Hz}, 2 \mathrm{H}, \mathrm{M}_{-} \mathrm{Ar}$ ), 7.00 (d, J $8.5 \mathrm{~Hz}, 2 \mathrm{H}, 0-\mathrm{Ar}$ ), 7.06 (d, J $8.5 \mathrm{~Hz}, 2 \mathrm{H}, \mathrm{M}_{-}-\mathrm{Ar}^{\prime}$ ), 8.46 (s, $1 \mathrm{H}, \mathrm{NCHN}) .{ }^{13} \mathrm{C}$ NMR $\left(125 \mathrm{MHz}, \mathrm{CDCl}_{3}\right): \delta=14.27,14.38,35.41,36.19,36.39,45.13,46.40,63.15,63.02,63.74$, 68.98, 69.24, 116.93, 117.03, 126.78, 126.96, 131.15, 131.18, 156.78, 158.02, 158.04, 169.44, 169.59, 169.85. ${ }^{15} \mathrm{~N} \mathrm{NMR}\left(50 \mathrm{MHz}, \mathrm{CDCl}_{3}\right): \delta=120.25 .{ }^{19} \mathrm{~F} \mathrm{NMR}\left(470 \mathrm{MHz}, \mathrm{CDCl}_{3}\right): \delta=-76.04 . \mathrm{HRMS}-\mathrm{ESI}: \mathrm{m} / z\left[\mathrm{M}-\mathrm{CF}_{3} \mathrm{CO}_{2}\right]^{+}$ calcd for $\mathrm{C}_{29} \mathrm{H}_{38} \mathrm{~N}_{2} \mathrm{O}_{8}$ : 541.2544; found 541.2550.

\section{Acknowledgements}

This work was supported by the Russian Science Foundation (grant no. 14-33-00022).

We are grateful to Dr. A. A. Tabolin (N. D. Zelinsky Institute of Organic Chemistry, Russian Academy of Sciences) for chiral HPLC analysis.

\section{References}

1. Filler, R.; Banks, R. E. Organofluorine chemicals and their industrial applications; Eds.; Ellis Horwood: Chichester, 1979; p 255.

2. Welch, J. T. Tetrahedron. 1987, 43, 3123.

http://dx.doi.org/10.1016/S0040-4020(01)90286-8

3. Frezza, M.; Balestrino, D.; Soulere, L.; Reverchon, S.; Queneau, Y.; Forestier, C.; Doutheau, A. Eur. J. Org. Chem. 2006, 4731.

http://dx.doi.org/10.1002/ejoc.200600416

4. Buscemi, S.; Pace, A.; Piccionello, A.; Macaluso, G.; Vivona, N. J. Org. Chem. 2005, 70, 3288. http://dx.doi.org/10.1021/jo047766s

5. Bohacek, R. S.; McMartin, C.; Guida, C. W. Med. Res. Rev. 1996, 16, 3. https://dx.doi.org/10.1002/(SICI)1098-1128(199601)16:1\%3C3::AID-MED1\%3E3.0.CO;2-6

6. Schlosser, M. in Enantiocontrolled synthesis of fluoroorganic compounds: stereochemical challenges and biomedical targets; Soloshonok, V. A., Eds.; Wiley: Chichester, 1999; p 613.

7. Michel, D.; Schlosser, M. Tetrahedron 2000, 56, 4253.

https://doi.org/10.1016/s0040-4020(00)00351-3

8. Agbaje, O. C.; Fadeyi, O. O.; Fadeyi, S. A.; Myles, L. E.; Okoro, C. O. Bioorg. Med. Chem. Lett. 2011, $21,989$. http://dx.doi.org/10.1016/j.bmcl.2010.12.022

9. Azaryan, L.V.; Avetisyan, S. A.; Buyukyan, N. S.; Chachoyan, A. A.; Garibdzhanyan, B. T. Pharm. Chem. J. 1997, 31, 282.

http://dx.doi.org/10.1007/BF02464114

10. Billman, J. H.; Meisenheimer, J. L. J. Med. Chem. 1964, 7, 115.

http://dx.doi.org/10.1021/jm00331a028

11. Billman, J. H.; Meisenheimer, J. L. J. Med. Chem. 1965, 8, 540.

http://dx.doi.org/10.1021/jm00328a033

12. Siddiqui, A. Q.; Merson-Davies, L.; Cullis, P. M. J. Chem. Soc., Perkin Trans. 1 1999, 3243.

http://dx.doi.org/10.1039/a903293b 
13. Groszkowski, S.; Korzycka, L.; Bilasiewicz, W. Pol. J. Pharm. Pharm. 1973, 25, 573.

PMID: 4792477

14. Braekman, J. C.; Daloze, D.; Flammang, R.; Maquestiau, A. Org. Mass Spectrom. 1989, $24,837$.

http://dx.doi.org/10.1002/oms.1210240919

15. Drandarov, K.; Guggisberg, A.; Hesse M. Helv. Chim. Acta, 1999, 82, 229.

http://dx.doi.org/10.1002/(SICI)1522-2675(19990210)82:2\%3C229::AID-HLCA229\%3E3.0.CO;2-H

16. Liu, S.-W.; Jin, J.; Chen, C.; Liu, J.-M.; Li, J.-Y.; Wang, F.-F.; Jiang, Z.-K.; Hu, J.-H.; Gao, Z.-X.; Yao, F.; You, X.-F.; Si, S.-Y.; Sun, C.-H. J. Antibiot. 2013, 66, 281.

https://dx.doi.org/10.1038/ja.2012.118

17. Horvath, D. J. Med. Chem. 1997, 40, 2412.

http://dx.doi.org/10.1021/jm9603781

18. Ozalp, M.; Calıs, U.; Koksal, M. Hacettepe University Journal of Faculty of Pharmacy, 2000, $20,37$.

19. Bisceglia, J. A.; Garcia, M. B.; Massa, R.; Magri, M. L.; Zani, M.; Gutkind, G. O.; Orelli L. R. J. Heterocycl. Chem. 2004, 41, 85.

http://dx.doi.org/10.1002/jhet.5570410113

20. Aytemir, M. D.; Calis, U.; Ozalp, M. Hacettepe University Journal of Faculty of Pharmacy, 2002, 22, 9.

21. Shakirov, R. R.; Yarmukhamedov, N. N.; Vlasova, L. I.; Baibulatova, N. Z.; Khisamutdinova, R. Yu.; Gabdrakhmanova, S. F.; Karachurina, L. T.; Baschenko, N. Zh. Pharm. Chem. J. 2006, 40, 29.

http://dx.doi.org/10.1007/s11094-006-0051-5

22. Hwang, J. Y.; Kim, H.-Y.; Jo, S.; Park, E.; Choi, J.; Kong, S.; Park, D.-S.; Heo, J. M.; Lee, J. S.; Ko, Y.; Choi, I.; Cechetto, J.; Kim, J.; Lee, J.; No, Z.; Windisch, M. P. Eur. J. Med. Chem. 2013, 70, 315.

https://dx.doi.org/10.1016/j.ejmech.2013.09.055

23. Janati, F.; Heravi, M. M.; Mirshokraie, A. J. Chem. 2013, 5, 214617.

http://dx.doi.org/10.1155/2013/214617

24. Zohdi, H. F.; Rateb, N. M.; Elnagdy S. M. Eur. J. Med. Chem. 2011, 46, 5636.

http://dx.doi.org/10.1016/j.ejmech.2011.09.036

25. Saloutin, V. I.; Burgart, Ya. V.; Kuzueva, O. G.; Kappe, C. O.; Kappe, O. N.; Chupakhin O. N. J. Fluorine Chem. 2000, 103, 17.

http://dx.doi.org/10.1016/S0022-1139(99)00216-X

26. Reddy, Ch. V.; Mahesh, M.; Raju, P. V. K.; Babu, T. R.; Reddy, V. V. N. Tetrahedron Lett. 2002, 43, 2657. http://dx.doi.org/10.1016/S0040-4039(02)00280-0

27. Ryabukhin, S. V.; Plaskon, A. S.; Ostapchuk, E. N.; Volochnyuk, D. M.; Shishkin, O. V.; Tolmachev, A. A. J. Fluorine Chem. 2008, 129, 625.

http://dx.doi.org/10.1016/j.jfluchem.2008.05.004

28. Sathicq, A. G; Ruiz D. M.; Constantieux, T.; Rodriguez, J.; Romanelli, G. P. Synlett 2014, 25, 0881.

https://dx.doi.org/10.1055/s-0033-1340845

29. Palermo, V.; Sathicq, A.; Constantieux, T.; Rodriguez, J.; Vazquez, P.; Romanelli, G. Catal. Lett. 2015, 145, 1022.

http://dx.doi.org/10.1007/s10562-015-1498-3

30. Martinez, J. J.; Nope, E.; Rojas, H.; Cubillos, J.; Sathicq, A. G.; Romanelli, G. P. Catal. Lett. 2014, $144,1322$. http://dx.doi.org/10.1007/s10562-014-1267-8

31. Suresh; Sandhu, J. S. Arkivoc, 2012, 1, 66.

http://dx.doi.org/10.3998/ark.5550190.0013.103 
32. Latypova, D. R.; Badamshin, A. G.; Lobov, A. N.; Dokichev, V. A. Russ. J. Org. Chem. 2013, 49, 843. http://dx.doi.org/10.1134/S1070428013060079

33. Mukhopadhyay, C.; Rana, S; Butcher, R. J. Tetrahedron Lett. 2011, 52, 4153. http://dx.doi.org/10.1016/j.tetlet.2011.05.144

34. Neochoritis, C. G.; Eleftheriadis, N.; Tsiantou, A.; Stephanidou-Stephanatou, J.; Tsoleridis, C. Synlett 2013, $24,2768$.

https://dx.doi.org/10.1055/s-0033-1339922

35. China Raju, B.; Suman, P. Chem. Eur. J. 2010, 16, 11840. http://dx.doi.org/10.1002/chem.201000883

36. Burgart, Ya. V.; Kuzueva, O. G.; Pryadeina, M. V.; Kappe, C. O.; Saloutin, V. I. Russ. J. Org. Chem. 2001, 37, 869.

http://dx.doi.org/10.1023/A\%3A1012473901354

37. Yang, L.; Bian, H.; Mai, W.; Mao, P.; Xiao, Y.; Wei, D.; Qu, L. Turk. J. Chem. 2015, 39, 121. http://dx.doi.org/10.3906/kim-1404-67

38. Brown, D. J.; Evans, R. F. J. Chem. Soc., 1962, 4039.

http://dx.doi.org/10.1039/JR9620004039 